\title{
Development of human fetal mesenchymal stem cell mediated tissue engineering bone grafts
}

\author{
Zhiyong Zhang ${ }^{1,2}$, Swee-Hin Teoh ${ }^{1,2,3}$, Mahesh Choolani4, Jerry Chan ${ }^{4}$ \\ 1 Mechanical Engineering, Faculty of Engineering, National University of Singapore, \\ Singapore \\ 2 Centre for Biomedical Materials Applications and Technology (BIOMAT), National \\ University of Singapore, Singapore \\ 3 National University of Singapore Tissue Engineering Programme (NUSTEP), National \\ University of Singapore, Singapore \\ 4 Experimental Fetal Medicine Group, Department of Obstetrics \& Gynaecology, Yong \\ Loo Lin School of Medicine, National University of Singapore, Singapore \\ 5 Department of Reproductive Medicine, KK Women's and Children's Hospital, Singapore \\ 6 Cancer and Stem Cell Biology Program, Duke-NUS Graduate Medical School, Singapore
}

\section{Fracture treatment and bone tissue engineering}

Although bone is a dynamic and well-vascularized tissue with innate healing and remodeling capacities (Salgado et al., 2004), up to $10 \%$ of the bony fractures are complicated by non-union (Einhorn, 1995; Hayda et al., 1998; Marsh, 1998; Salgado et al., 2004; Bongso, 2005), which require additional treatment with bone grafts in order to achieve defect union and healing. In fact, bone grafts has become the second most transplanted tissue in the world after blood, with approximately one million cases of bone graft transplantation occurring in United States alone annually (Salgado et al., 2004; Bongso, 2005).

Bone grafts can be categorized into three types: autografts, allografts, and synthetic grafts, with their relative frequency of use illustrated in Figure 1 and a comparison of their advantages and disadvantages in Table 1. Autografts are harvested from a secondary site from the patient's own body, commonly the iliac crest. This strategy has been described initially by Chutro and later Phemister in early 20th century (Connolly et al., 1991) , and has been considered the gold standard for many decades. This is because the use of autografts results in the the best clinical outcomes by providing both osteogenic cells and essential osteoinductive factors required for bone healing. However, the use of autografts has been limited by its availability, difficulty in fashioning of grafts to fit defects, an unpredictable efficacy and complexity of two surgeries (Banwart et al., 1995; Fowler et al., 1995; Goulet et al., 1997; Salgado et al., 2004; Hollinger et al., 2005). Futhermore, significant donor site morbidity such as chronic pain, hypersensitivity, infection and paraesthesia occur in up to a third of patients (Prolo and Rodrigo, 1985; Damien and Parsons, 1991; Arrington et al., 1996; Lane et al., 1999). Allografts, bone grafts harvested from another donor (mainly from cadavers), are an alternative with enhanced flexibility of graft size and shapes. However, 
they introduce the possibility of immune rejection and pathogen transmission. Moreover, processing techniques, such as demineralization, strip the tissue of osteoinductive factors necessary for stimulating bone repair, resulting in impeded healing times, as compared to autografts (Parikh, 2002) . Synthetic grafts are made from metals or ceramics, which can be fashioned to different shapes and sizes and are non-immunogenic, but thus far have been hampered by their poor speed of healing and inability to remodel in tandem with the natural healing process (Salgado et al., 2004).

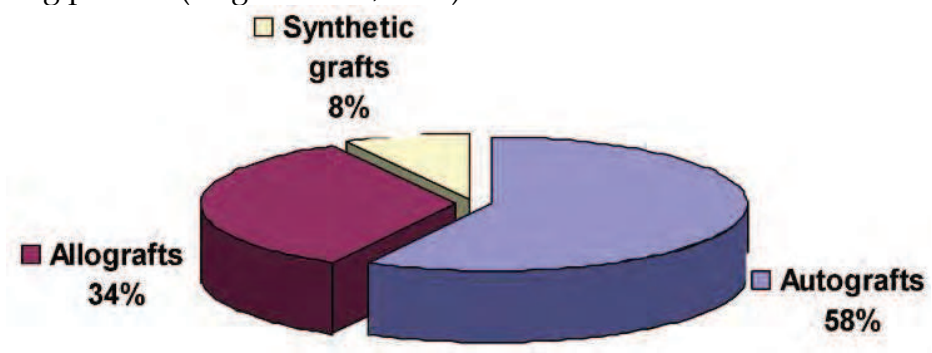

Fig. 1. Breakdown of the current used bone grafts: autograft, allograft and synthetic graft.

\begin{tabular}{l|l|l|l|l|l|l}
\hline & Healing & Remodelling & $\begin{array}{l}\text { Immuno- } \\
\text { genicity }\end{array}$ & Availability & $\begin{array}{l}\text { Surgery } \\
\text { simplicity }\end{array}$ & Others \\
\hline Autografts & +++ & +++ & - & + & + & $\begin{array}{l}\text { donor-site } \\
\text { morbidities }\end{array}$ \\
\hline Allografts & ++ & ++ & + & +++ & +++ & $\begin{array}{l}\text { disease } \\
\text { transmission }\end{array}$ \\
\hline $\begin{array}{l}\text { Synthetic } \\
\text { grafts }\end{array}$ & + & 0 & - & +++ & +++ & $\begin{array}{l}\text { fatigue, } \\
\text { fracture, } \\
\text { wear }\end{array}$ \\
\hline $\begin{array}{l}\text { Tissue } \\
\text { engineered } \\
\text { grafts }\end{array}$ & +++ & +++ & - & +++ & +++ & \\
\hline
\end{tabular}

Table 1. Comparison of different bone grafts

Thus, in order to fulfill this increasing but unmet clinical need for effective bone grafts, recent research efforts have turned to a tissue engineering approach to develop tissue engineered grafts, which not only have off-the-shelf availability in various shapes and sizes (like allografts and synthetic grafts), but have the ability to stimulate rapid bone healing and undergo remodeling, achieving a better or similar clinical outcome than or as autografts (Table 1).

\section{Cell based strategy vs. Growth factor based strategy}

Tissue Engineering was first coined by Langer and Vacanti in 1993 as "an interdisciplinary field of research that applies the principles of engineering and the life sciences towards the development of biological substitutes that restore, maintain, or improve tissue function"(Langer and Vacanti, 1993). Since then, several different bone tissue engineering (BTE) approaches have been proposed and explored. In essence, they can be classified into 
two main categories of a cell or a growth factor based strategy. Both approaches seek to create an optimized bone growing bed with a biological microenvironment suitable for bone regeneration through introducing a critical mass of osteogenic cells onto the scaffold matrix and modulating intercellular communication and cell-matrix interactions. However, the manner in which the introduction of osteogenic cells is different. Cell-based approaches supply exogenous osteogenic cells while relying on the autologous growth factors from the repair site to stimulate bone regeneration, whereas growth factor-based approaches rely on the delivery of growth factors to recruit osteogenic cells from the local environment into the repair site. (Kimelman et al., 2007; Lanza et al., 2007).

The use of growth factor-based BTE approaches has been shown to be efficacious in small animal models. However, the translation from small animal models, through large animal models, to humans has proven to be difficult and the optimal dose of growth factors for human clinical therapy is difficult to determine, because of the large variation of efficacy between small to big animals (up to 100 fold). Another problem relates to the problem of develping an effective delivery and release approach, given the short half-life of the majority of the growth factors are (Hollinger et al., 1996; Bruder and Fox, 1999). In addition, growth factor-based approaches work indirectly by attracting and stimulating the proliferation and differentiation of local osteogenic stem cells to repair bone defect, therefore its effectiveness will be greatly compromised in the absence of sufficient osteogenic stem cell pool (Service, 2000). In contrast, a cell-based approach works independently of the presence of local osteogenic cells, and therefore is an attractive therapy for patients with a diminished pool of osteogenic progenitors such as those with severe trauma, diabetes, a history of tobacco use, irradiation, aging, osteoporosis or other metabolic derangements (Bruder and Fox, 1999). Furthermore, delivering the right quantity of different growth factors in a sequential manner reflecting the different phases of bone growth faces multiple technical challenges (Marsh and Li, 1999; Giannoudis et al., 2007). In contrast, cell-based strategies utilize osteogenic cells which secrete a wide spectrum of growth factors at physiological doses, establishing temporal-spatial microgradients necessary for effective bone regeneration (Rouwkema et al., 2008). Thus, cell based strategies have been pursued in our group.

Two distinct typical cell-based approaches have been proposed to use cultured osteogenic cells in combination with scaffold matrix to engineer bone grafts (Hollinger et al., 2005; Lieberman and Friedlaender, 2005; Lanza et al., 2007). The first approach is to seed cells on the scaffold matrix and the immediate implantation of the resulting construct (Figure $2 \mathrm{~A}$ ). In the second approach, a period of in vitro culture is performed for cellular expansion and osteogenic pre-differentiation (Figure $2 \mathrm{~B}$ ), which has been shown to result in significantly higher degree of bone defect healing compared to an immediate implantation approach (Mendes et al., 2002; Sikavitsas et al., 2003; De et al., 2006; Dudas et al., 2006) . In this delay implantation approach, osteogenic cells are seeded into three dimensional highly porous biodegradable scaffolds with the desired shape to fit the bone defect. These cellular scaffolds are then cultured and matured in a suitable in vitro environment for cellular expansion and proper pre-differentiation to obtain bone-like constructs with extracellular mineralized matrix and pre-differentiated cells. Finally, the grafts are implanted into the defect to induce and direct the growth of new bone with the controlled degradation of the scaffold matrix (Figure 2B). 
A
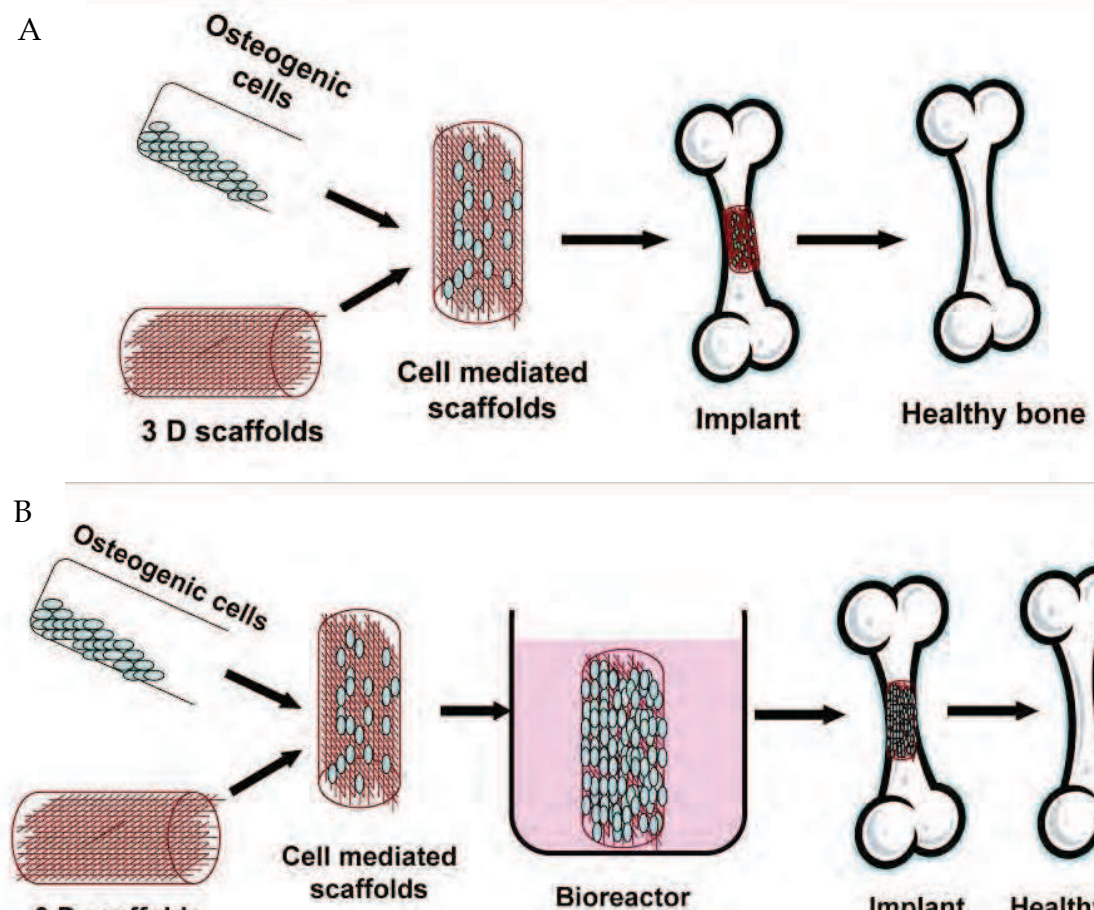

3 D scaffolds

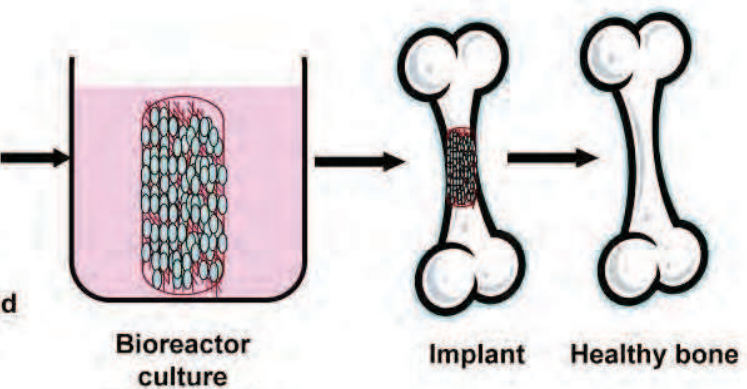

( TE bone graft)

Fig. 2. Two cell based BTE approaches.

\section{Polycaprolactone based scaffolds for BTE application}

To generate an effective TE bone grafts, three dimensional (3D) scaffolds are required to function as a supportive matrix for cell proliferation, extracellular matrix deposition and consequent bone in-growth and at the same time define the overall shape of the tissue engineered transplant (Laurencin et al., 1999). Moreover, the 3D scaffolds should have rigid mechanical properties to protect the defect area from collapse of surrounding tissue, and proper macroporous structure to prevent the invasion of fibrous tissue but allow the infiltration of blood vessels. Scaffolds should also actively contribute to the regenerative process by enhancing the proliferation and osteogenic differentiation of the cells grew on their surface through the cell-scaffold interaction (Agrawal and Ray, 2001).

Our group has extensively investigated the use of Fused Deposition Modeling (FDM) technique to fabricate the porous three dimensional (3D) scaffolds for BTE applicaiton (Hutmacher et al., 2001; Zein et al., 2002). A polycaprolactone and tricalcium phosphate composite material was selected for the scaffold fabrication. Poly ( $\varepsilon$-caprolactone) (PCL) is a semicrystalline, bioresorbable polymer belonging to the aliphatic polyester family. It is highly processable, with low glass-transition temperature $\left(-60^{\circ} \mathrm{C}\right)$ and melting point $\left(60^{\circ} \mathrm{C}\right)$ but high decomposition temperature of $350^{\circ} \mathrm{C}$. It has been previously exploited for drug delivery material (Coombes et al., 2004) and demonstrated great biocompatibility with US 
Food and Drug Administration (FDA) approval for its use in several medical and drug delivery devices. It has slow degradation kinetics of only seven percent over a six month in vivo (Lam et al., 2008), and thus is suitable for utilisation in load bearing bone grafting applications, which requires a prolonged period of mechanical support. In addition, chemical hydrolysis as opposed to enzymatic reactions is responsible for degradation of polymeric chains in vivo; thus degradation does not vary from patient to patient.

However, PCL is not without drawbacks, as with all synthetic polymers, PCL implants experience fibrosis and gradually become isolated from the surrounding bone. Consequently, they do not adhere to bone and this has been a critical problem in their use in bone repair (Kokubu et al., 2003). In addition, a common problem to biodegradable polyesters family is that the bulk release of acidic degradation products can cause acidosis (Ciapetti et al., 2003). This led to the search for additional compounds to modify PCL for BTE applications.

$\beta$-tricalcium phosphate (TCP), a synthetic ceramic material, is one such compound. Firstly, TCP is bioactive and can generate a carbonated hydroxyapatite layer on its surface that is equivalent chemically and structurally to the biological mineral of nature bone, known as the determining step for the biointegration (Kokubo et al., 2003). Secondly, TCP is osteoconductive and can promote the cellular adhesion, function and expression leading to formation of new bone and a uniquely strong bone-TCP biomaterial interface. Finally, TCP is reported to be osteoinductive, and capable of binding and concentrating endogenous bone morphogenetic proteins from the circulation (LeGeros, 2002). However, pure TCP is a brittle material with very poor mechanical properties, leading to difficulties with its processing for BTE applications. To overcome these shortcomings, a bioactive composite material comprising of a biodegradable polymeric phase (PCL) and a bioactive inorganic phase (TCP) has been developed. This construct takes advantage of the flexibility and processability of the bulk PCL polymer phase, combined with TCP bioactive phase, allowing the scaffold to bond and integrate with bone spontaneously and possess both osteoconductive and osteoinductive properties. Furthermore, the acidic release from the polymer can be compensated by the alkaline calcium phosphate (Blaker et al., 2003; Maquet et al., 2004) . (Figure 3) 


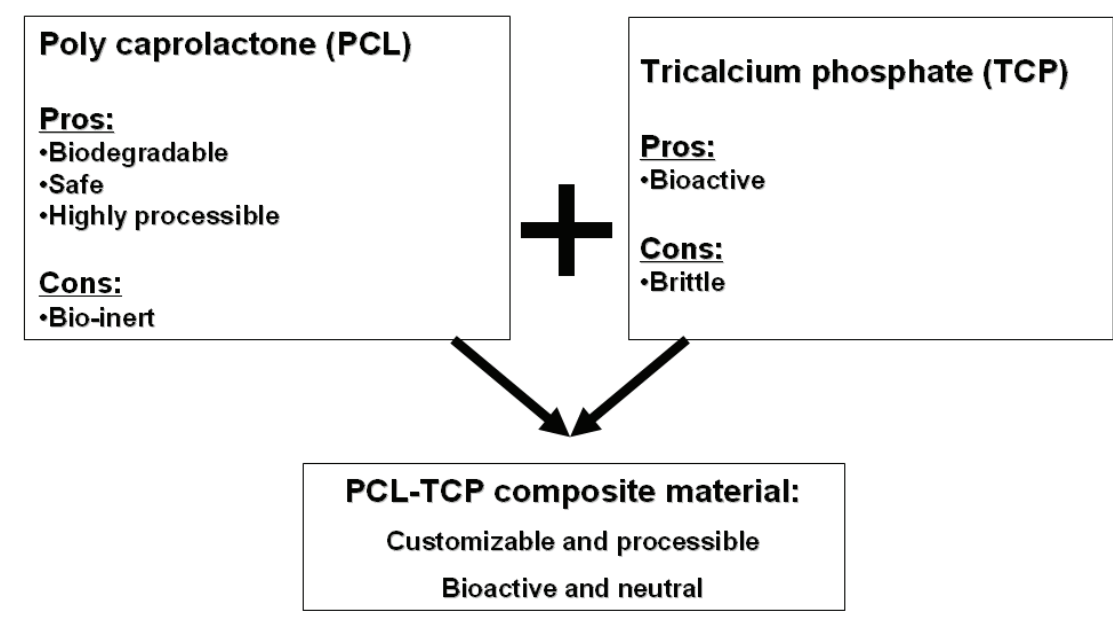

Fig. 3. PCL-TCP composite material, incorporates the strength of PCL and TCP while neutralizes their individual drawbacks

FDM, as a solvent-free rapid prototyping technique, was utilized to fabricate the PCL-TCP composite material into 3D scaffolds (Hutmacher et al., 2001; Zein et al., 2002) in three steps. Firstly, the PCL-TCP filament were fabricated by physically blending the PCL pellets with TCP granules in a desired ratio (e.g. $80 \%$ PCL to $20 \%$ TCP), melting in a high temperature $\left(190^{\circ} \mathrm{C}\right)$ and extruding through spinnerets with a die exit diameter of $1.63 \mathrm{~mm}$. Secondly, the size and shape of the scaffolds were designed through computer assisted design (CAD) systems, for example, patient-specific scaffolds can be created based on the 3D computed tomography(CT) images, then these CAD models were imported into the Stratasys QuickSlice software and sliced into the horizontal layers. The deposition path were created and downloaded to the FDM machine, the 3D Modeler RP system from Stratasys Inc. (Eden Prairie, MN). Lastly, PCL-TCP filament prepared were fed into the FDM head, melted down in the liquefier and extrude out through the nozzle tip and deposit on a platform layer by layer according to the preprogrammed deposition path.

We have fabricated PCL-TCP scaffolds to achieve a honeycomb architecture, with a fully interconnected matrix, and mechanical properties close to cancellous bone. This should allow rapid vascularization to occur and maintain the defect space and the structural integrity of tissue engineered bone grafts in load-bearing applications (Hutmacher et al., 2001; Schantz et al., 2002) (Figure 4). In addition, use of the highly reproducible and computer-controlled FDM technique allows the fabrication of tissue-engineered grafts that have been designed on the basis of computed tomography (CT) scans of individual defect sites(Hutmacher, 2000; Endres et al., 2003) . PCL-TCP scaffolds have a favourable profile for achieving effective cellular adhesion, proliferation and differentiation in vitro (Rai et al., 2004; Zhang et al., 2009; Zhang et al., 2009) , and serve as an osteoconductive matrix for new bone regeneration in both critical-sized rat femoral (Rai et al., 2007) and canine mandibular defects (Rai et al., 2007). 


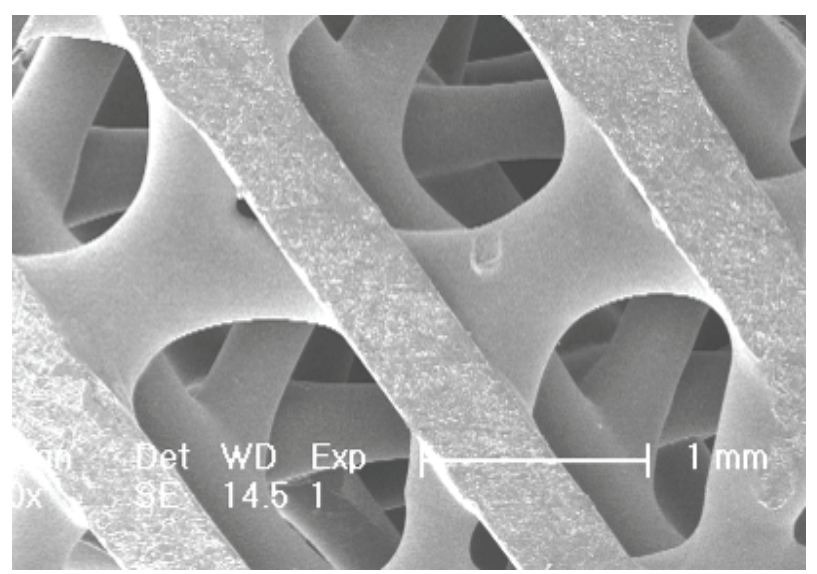

Fig. 4. Scanning Electronic Microscopy (SEM) image of PCL-TCP scaffolds

\section{Human fetal mesenchymal stem cells for BTE application}

\subsection{Available cellular sources for cell based BTE}

Cells are the central players for most biological process in human body. As the critical component in the BTE strategy, they play the most essential role and are directly involved in bone regeneration. The selection of cell sources will eventually determine the success of any BTE strategy. An ideal cellular source for cell-based BTE approach should include the following characteristics: (1) no immunogenicity, (2) no tumorigenicity, (3) immediate availability, (4) availability in pertinent quantities, (5) rapid cell proliferation rate, (6) predictable and consistent osteogenic potential as well as; (7) controlled integration into the surrounding tissues (Logeart-Avramoglou et al., 2005) . Different cell sources have been exploited for BTE applications, and can be divided into three categories with the respect to their differentiation status: fresh bone marrow, differentiated osteoblasts and mesenchymal stem cells (Bruder and Fox, 1999; Pioletti et al., 2006) (Table 2).

Fresh bone marrow (BM) has been introduced to heal nonunion bone defects some three decades ago (Connolly et al., 1989; Connolly et al., 1991; Caplan, 2005). BM are readily harvested and contain the osteogenic progenitors, which can enhance bone regeneration. As they are autologous tissues, immunorejection is not an issue, nor are they subject to the regulation by the Food and Drug Administration (FDA) (Bruder and Fox, 1999) . However, their effectiveness is highly dependent on the number of the osteogenic progenitors, which represent approximately $0.001 \%$ of the nucleated cell in the healthy bone marrow at best (Bruder et al., 1997) and decreases dramatically with aging or disease process (Pioletti et al., 2006). Thus, this approach may be least applicable in those situations where it is most needed, as fractures tend to occur more frequently in an old age group. Moreover, the use of unmatched allogenic BM is not suitable, as it is beset by problems of either graft rejection or graft-versus-host syndrome (Weissman, 2000).

Osteoblasts participate in bone formation processes via the synthesis and secretion of collagen fibres to form unmineralized bone matrix (osteoid), and have been implicated in osteoid calcification. The use of osteoblasts for the cellular source for BTE applications has demonstrated enhancement in the rate and extent of bone regeneration compared with the 
use of undifferentiated bone marrow (Okumura et al., 1997; Bruder and Fox, 1999; Montjovent et al., 2004). However, autologous isolation of the osteoblasts is considerably more difficult and complex than fresh bone marrow or mesenchymal stem cells. In addition, they posses a limited capacity for proliferation, and thus do not support in the generation of significant cell numbers for clinical use (Bruder and Fox, 1999; Montjovent et al., 2004; Pioletti et al., 2006).

Mesenchymal stem cells (MSC) are also known as marrow stromal cell or colony forming unit - fibroblast (CFU-F) or more recently named as multipotent mesenchymal stromal cells by International Society for Cellular Therapy (ISCT) (Dominici et al., 2006) . They were first identified and isolated from adult bone marrow (Friedenstein et al., 1966; Friedenstein et al., 1968) and demonstrated a series of favorable advantages for BTE application over other cell sources. Firstly, MSC are easily isolated through plastic adhesion method or simple antibody selection techniques (Simmons and Torok-Storb, 1991). Secondly, the osteogenic differentiation pathway is well defined and MSC have been shown to generate greater amount of bone tissue than fresh bone marrow in preclinical studies (Kahn et al., 1995; Inoue et al., 1997; Pioletti et al., 2006). Thirdly, both undifferentiated and differentiated MSC have been reported as non-immunogenic, and are thus suitable for allogeneic applications (Le Blanc et al., 2003) . Finaly, cryostorage does not affect the osteogenic potential of MSC, which greatly facilitates their storage (Bruder et al., 1997).

\begin{tabular}{c|c|c|c|c|c}
\hline & Collection & Expansion & Storage & $\begin{array}{c}\text { Allogenic } \\
\text { applications }\end{array}$ & $\begin{array}{c}\text { Osteogenic } \\
\text { potential }\end{array}$ \\
\hline $\begin{array}{c}\text { Fresh bone } \\
\text { marrow }\end{array}$ & +++ & N.A. & N.A. & N.A. ${ }^{*}$ & + \\
\hline Osteoblast & + & + & + & N.A. $^{*}$ & +++ \\
\hline MSC & ++ & ++ & +++ & ++ & ++ \\
\hline
\end{tabular}

N.A.*: allogenic applications can be achieved by proper HLA matching

Table 2. Comparison of different cellular source for BTE.

\subsection{MSC biology}

Although there are no specific cell markers to distinguish MSC from other cell types, MSC are generally defined by their capabilities to (1) adhere to the plastic surface of tissue culture flask; (2) express D105, CD73 and CD90, with absence of CD45, CD34, CD14 or CD11b, CD79a or CD19 and HLA II; and (3) differentiate into the osteoblasts, adipocytes and chondroblasts under standard in vitro differentiating conditions (Dominici et al., 2006). MSC are rare cells, and exist at low frequencies in human adult $\mathrm{BM}$, accounting for $0.00001 \%$ to $0.001 \%$ of mononuclear cells (MNC) in BM. They are non-haemopoietic and can be separated from the haemopoietic fraction in BM by their adherence to plastic and ability to grow from an initial heterogeneous population into a more homogenous spindle-shaped cell type. MSC have been demonstrated to contain a heterogeneous population of cells. Properties including colony size, proliferation rate, cellular morphology, and multipotency both in vitro and in vivo have been routinely observed to differ in single colony-derived MSC strains (Muraglia et al., 2000; Mauney et al., 2005) . Other techniques for isolation of MSC include immuno-depletion (Baddoo et al., 2003) or immuno-selection techniques with STRO-1 and CD 271 antibodies (Simmons and Torok-Storb, 1991; Jones and McGonagle, 2008). However, the resulting cultures are still heterogeneous, ranging from spindle shaped cells to broad stromal-like cells (Digirolamo et al., 1999; Colter et al., 2000; Colter et al., 2001) 
This is also reflected in intra-sample and inter-species differences in the capacity of MSC to self-renew or form CFU-F in low-density cultures (Digirolamo et al., 1999; Phinney et al., 1999; Banfi et al., 2000; Javazon et al., 2001).

MSC are not inherently immunogenic, making them highly attractive for allogeneic transplantation strategies (Caplan, 2007). MSC are HLA Class I positive and Class II negative and do not express co-stimulatory molecules CD40, CD40L, CD80, or CD86 (Klyushnenkova et al., 2005) . This phenotype is widely regarded as non-immunogenic and suggests that MSC may be effective at inducing tolerance. In the mixed lymphocyte cultures (MLC) assay, MSC do not elicit a proliferation response of allogeneic lymphocytes (Bartholomew et al., 2002; Le Blanc et al., 2003). After interferon $\gamma$ (INF- $\gamma$ ) induction of HLA II expression, MSC are still capable of escaping recognition by alloreactive T-cells (Le Blanc et al., 2003; Klyushnenkova et al., 2005). Similarly, after cellular differentiation into along the adipogenic, chondrogenic and osteogenic lineages, they remain non-immunogenic (Le Blanc, 2003). MSC have been found to escape lysis by cytotoxic T-cells and alloreactive killer inhibitory receptor mismatched natural killer cells (Le Blanc, 2003; Rasmusson et al., 2003; Gotherstrom, 2007) , making them uniquely suited for allogeneic transplantation applications.

In addition to being non-immunogenic, MSC have been shown to possess immunomodulatory properties both in vitro and in vivo. In vitro, they exhibit immunosuppressive effects and inhibit T-cell alloreactivity (Pittenger et al., 1999; Bartholomew et al., 2002; Krampera et al., 2003; Maitra et al., 2004; Beyth et al., 2005). This suppression effect of MSC is dose dependent and not only influence T cell but also affect the differentiation and maturation of dendritic cells from monocytes (Aggarwal and Pittenger, 2005). In vivo, infusion of ex vivo-expanded MSC has been shown to prolong the survival of allogeneic major histocompatibility mismatched skin allografts in immunocompetent outbred baboons (Bartholomew et al., 2002). Further evidence was provided by Djouad et al, who found that subcutaneously injected melanoma cells in allogeneic immunocompetent mice formed tumors only when co-injected with MSC, suggesting that the presence of MSC prevented immune rejection of the tumor cells (Djouad et al., 2003). More recently MSC have been used to treat graft-versus-host disease (GvHD) after allogeneic hematopoietic stem cell transplantation (Le Blanc et al., 2008). The mechanism governing those effects is not yet understood. However, it is quite likely that the paracrine effect of MSC will play a significant role in it, for example, it was shown that MSC may strongly inhibit T-cell recognition and expansion via inhibiting TNF- $\alpha$ and INF- $\gamma$ production and, thus, increasing IL-10 levels. (Aggarwal and Pittenger, 2005; Beyth et al., 2005; Caplan, 2007)

MSC are currently defined by their trilineage differentiation capacity (osteogenic, adipogenic and chondrogenic differentiation). In addition, they have been shown to be able to differentiate to muscle, marrow stroma and other connective tissues (Caplan, 1991; Caplan, 2005; Caplan, 2007). Several reports have now expanded repertoire to neuroectodermal lineages such as neurons (Woodbury et al., 2000; Zhao et al., 2002), hepatocyte (Ong et al., 2006; Banas et al., 2007; Sgodda et al., 2007) and endothelial cell (Oswald et al., 2004; Gang et al., 2006) . A subset of MSC, termed Multipotent adult progenitor cells (MAPC), have been isolated from a number of species. MAPCs have greater differentiation potential than MSC, and have been shown to be pluripotent (Reyes et al., 2001; Jiang et al., 2002). However they are difficult to isolate and have not been reliably reproduced by other laboratories. 
The osteogenic differentiation pathway is the default pathway for MSC, which is retained regardless of cell passage number until senescence (Digirolamo et al., 1999). MSC are heterogenous in nature, and consist of subpopulations of cells with tri-potent (osteogenic, adipogenic and chondrogenic), bi-potent (osteogenic and chondrogenic) and uni-potent (osteogenic) differentiation capacities as demonstrated through clonal analysis (Muraglia et al., 2000). Clones have been found to progressively lose their adipogenic and chondrogenic differentiation potential at increasing cell doublings, although osteogenic differentiation ability is retained till senescence (Digirolamo et al., 1999; Muraglia et al., 2000) .

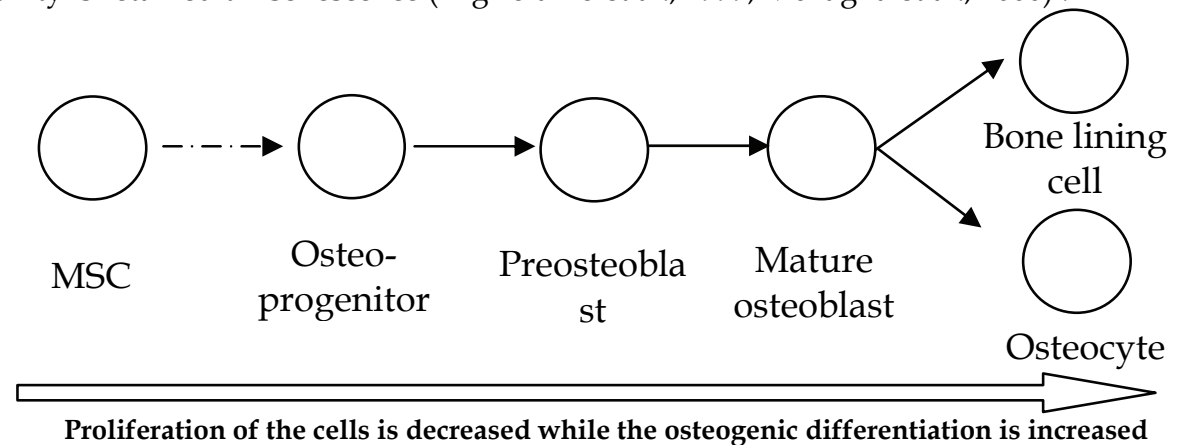

Fig. 5. Osteogenic differentiation pathway of MSC

Under the osteogenic differentiation pathway, MSC can be fully differentiated into osteoblasts, bone lining cells and osteocytes, which is a highly regulated and multi-step process with a sophisticated hierarchy as illustrated in Figure 5. MSC is likely to occupy the top position in this hierarchy, followed by osteoprogenitors, which are osteogenic committed progenitor cells with limited self-renewal and restricted differentiation capacity, but still maintaining substantial proliferation capacity. Further downstream are the preosteoblasts with more limited proliferation capacity. Mature osteoblasts are the terminally differentiated and functional cells, which will finally become the bone lining cells or osteocytes. With the progress of the osteogenic differentiation, proliferation of the cells is decreased while the osteogenic differentiation is increased. (Aubin, 1998; Aubin, 2001; Bilezikian, 2002)

\subsection{Limitations of adult BM derived MSC and alternative MSC sources}

The adult BM is the first tissue source where MSC are found and isolated, and are thus most investigated. They have been exploited as an autologous cell source for BTE applications, and demonstrated their effectiveness for fracture healing not only in animal but also in a number of reported human clinical trials (Quarto et al., 2001; Schimming and Schmelzeisen, 2004; Ueda et al., 2008; Yamada et al., 2008) . However, several barriers currently exist, limiting their further clinical applications. Firstly, adult BM-MSC are rare cells with a very low frequency, accounting for $0.00001 \%$ to $0.001 \%$ of mononuclear cells (MNC) in the adult bone marrow (BM). Furthermore, they have limited proliferative capacity, only undergoing an average approximately $38 \pm 4$ population doublings before reaching cellular senescence (Bruder et al., 1997). As a result, in order to obtain clinically significant cell numbers, a large amount of bone marrow aspiration is required initially. Secondly, for autologous usage, the 
derivation and expansion of MSC require a long period (4-6 weeks) for ex vivo expansion, limiting their clinical use, especially where the cells are required acutely. Secondly, the frequency of MSC within bone marrow and the proliferative capacity decrease dramatically as a function of donor age (it can drop from $0.001-0.0004 \%$ before the ages of 30 to 0.00025 $0.00005 \%$ after the ages of 50) (Caplan, 2007), with systemic diseases adversely affecting their numbers and function (Suzuki et al., 2001) . Similarly, the osteogenic differentiation ability in vitro and in vivo has also been found to be inversely correlated with donor age (Mueller and Glowacki, 2001) and reduced in several disease phenotypes (Rodriguez et al., 2000).

More recently, MSC with osteogenic potential have been isolated from a diverse range of other tissue types and ontogeny: (1) In postnatal tissue, MSC have been isolated from tissues as diverse as periosteum(Nakahara et al., 1991) , trabecular bone (Sakaguchi et al., 2004) , synovial membrane (De et al., 2001) , adipose tissue (Zuk et al., 2001) and peripheral blood (Eghbali-Fatourechi et al., 2005). (2) In perinatal tissues, MSC have been found in the umbilical cord (Sarugaser et al., 2005) , umbilical cord blood (Bieback et al., 2004; Lee et al., 2004) , amniotic fluid (in't Anker, P; Scherjon, S A; Kleijburg-van, Keur C; Noort, W A; Claas, F H; Willemze, R; Fibbe, W E; Kanhai, 2003; De et al., 2007) . (3) In the prenatal tissue, human fetal MSC have been isolated and characterized from first-trimester fetal blood, liver, and bone marrow (Campagnoli et al., 2001), second trimester bone marrow, spleen and lung (in't Anker P ; Noort, W A; Scherjon, S A; Kleijburg-van, Keur C; Kruisselbrink, A B; van, Bezooijen R; Beekhuizen, W; Willemze, R; Kanhai, H H; Fibbe, 2003), fetal metanephros (Almeida-Porada et al., 2002) , dermis (Zhao et al., 2005) , pancreas (Hu et al., 2003) and thymus (Rzhaninova et al., 2005) . While investigations into their basic biology, immunogenicity and osteogenic potential have been reported, MSC have not been systematically compared for bone tissue engineering applications. Hence, it remains unclear how these novel prenatal, perinatal and postnatal MSC sources compare with their standard adult BM MSC counterparts for osteogenic differentiation and potential for tissue engineering.

\subsection{Human fetal BM derived MSC (hfMSC) as a promising cellular source for BTE}

Recently, we reported a systematic investigation into four types of MSC from different ontological and anatomical origins in a direct head-to-head manner for BTE applications (Zhang et al., 2009). In this study, MSC were isolated from prenatal (human fetal bone marrow (hfMSC)), perinatal (human umbilical cord (hUCMSC)) and postnatal sources (human adult adipose tissue (hATMSC) and human adult bone marrow (haMSC)). In vitro comparative studies were performed in monolayer cultures and three dimensional bioactive scaffold cultures to investigate their proliferation capacity, osteogenic differentiation and mineralization, and in vivo ectopic bone formation.

hfMSC, haMSC, hUCMSC and hATMSC adopted a similar spindle-shaped morphology when cultured in monolayers, and expressed a consistent MSC immunophenotype which was negative for haemopoietic (CD14, CD34, CD45) and endothelial markers (CD31, and vWF), and positive for mesenchymal markers (CD105 (SH2), CD73 (SH3, SH4)), intracellular markers (Vimentin and Laminin) and cell adhesion molecules (CD29, CD44, CD 106, CD 90). All the four MSC types expressed HLA-I but not HLA-II and possessed the typical trilinage differentition capacities. However, compared with other MSC, hfMSC expressed a lower 
level of HLA-I and a higher level of Stro-1 with the implication of lower immunogenicity and higher osteogenic capacity.

In two-dimensional (2D) monolayer cultures, hfMSC proliferated fastest (population doubling time $32.3 \pm 2.5$ hours), followed by hUCMSC ( $54.7 \pm 4.3$ hours), hATMSC (70.4 \pm 3.6 hours), with the slowest being haMSC (116.6 \pm 22.4 hours, $n=3, p<0.01)$ (Figure 6A). In addition, hfMSC had significantly higher self-renewal ability, with $75.1 \pm 5.0 \%$ of cells forming colonies, compared to $37.5-47.5 \%$ of other three MSC (Figure 6B). When cultured in 3D bioactive scaffold, hfMSC proliferated rapidly and reached confluence within the scaffold, taking up all available spaces by Day 7, while other MSC types achieved confluence only at the end of the 28 day experimental period as shown by a doublestranded DNA (dsDNA) quantification method (Figure 6C). Furthermore, hfMSC mediated scaffold constructs showed more robustly upregulated of key osteogenic genes, deposited significantly higher mineralizaton and demonstrated greater osteogenic capacity compared to other MSC scaffold constructs, as evaluated by a series of assay methods including vonKossa staining, ALP activity, calcium deposition, calcium visualized on micro-CT and scanning electron-microscopy, and osteogenic gene expression (Figure 6D). Finally, subcutaneous implantation of these 3D constructs in immunodeficient NOD/SCID mice was performed to compare the osteogenic potential of MSC scaffolds in vivo. MSC scaffolds were cultured for two weeks in vitro as osteogenic pre-induction before implantation. Two months after implantation, all MSC scaffolds demonstrated neo-vascularization, with blood vessels infiltrating the scaffolds from the surrounding tissue macroscopically, and shared a similar chimerism rate of human cells in the murine tissue (60 to $67 \%$ chimerism) as demonstrated by human specific nuclear stain (lamins A/C), with infiltration of murine cells accounting for a third of the cellular population within the internal spaces of the scaffolds. Compared to other MSC scaffolds, hfMSC-mediated scaffolds generated more ectopic bone formation in vivo $(1.8-13.3 \mathrm{x}, \mathrm{p}<0.01)$ through micro-CT quantification (Zhang et al., 2009). 


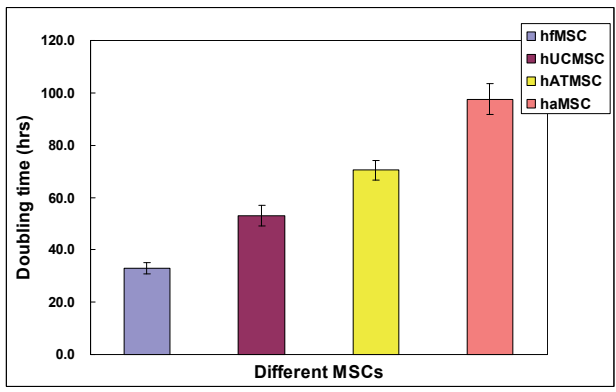

A. Doubling time of different MSCs

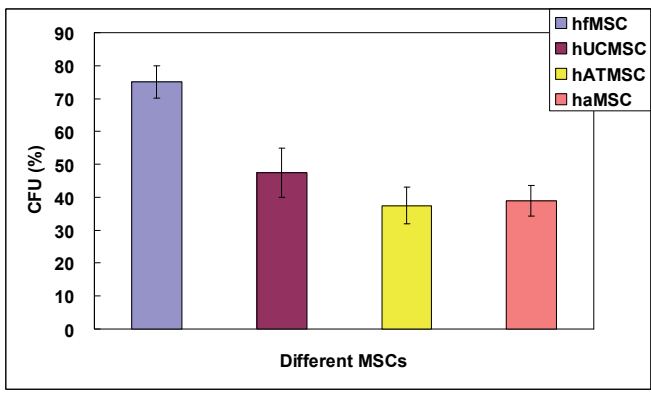

B. CFU of different MSCs

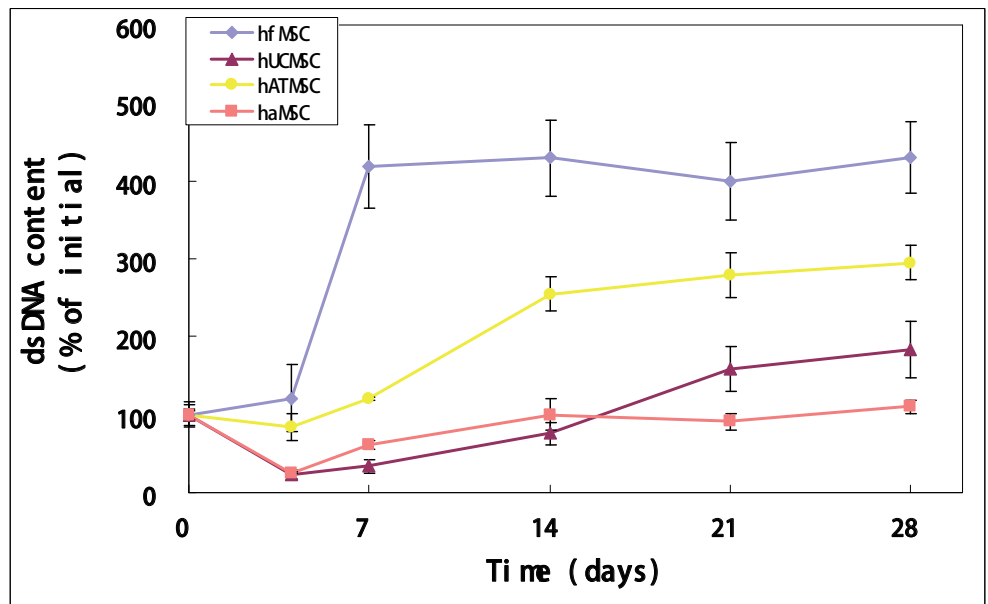

C. The cellularity of different MSC mediated scaffolds

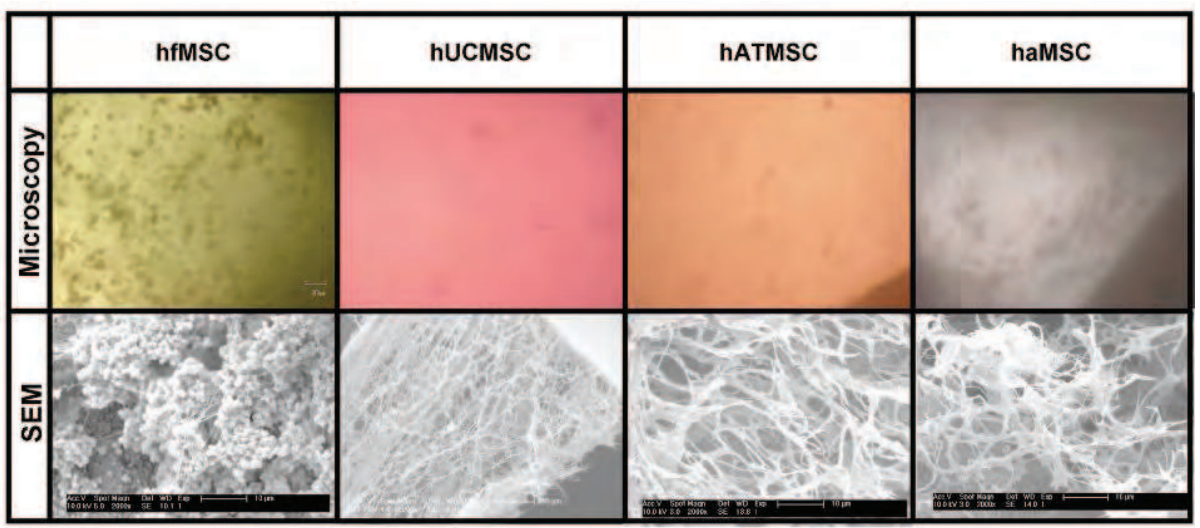

D. Osteogenic differentiation of MSC mediated scaffolds

Fig. 6. Comparison of different MSC for BTE application. (A) hfMSC proliferated faster than other MSCs with the shortest doubling time, and had higher self-renewal capacity on CFU-F 
assay (B-C) hfMSC expanded at a faster rate, reaching confluence by day 7 and have a higher final cellularity than other MSC mediated scaffolds. (D) hfMSC mediated scaffolds underwent more robust osteogenic differentiation and mineralization compared to others as seen through light microscopy and scanning electron microscopy (SEM).

Through this study, it was found that the ontological and anatomical origins of MSC have profound influences on the proliferative and osteogenic capacity of MSC. MSC from the ontologically more primitive source have higher proliferative capacities, while MSC from $\mathrm{BM}$ related origin showed more osteogenic potential than MSC from other origins. In summary, hfMSC had the most proliferative and osteogenic capacity of MSC sources, as well as being the least immunogenic, suggesting they are superior candidates for BTE applications.

\section{5 hfMSC as an off-the-shelf cellular source for BTE application}

hfMSC have different immunologic properties to haMSC, as illustrated in Table 3. hfMSC not only express significantly lower levels of HLA Class I than haMSC, they do express any intracellular HLA Class II, which are found haMSC. hfMSC require 7 days of interferongamma for the induction of HLA II expression, compared to 2 days for haMSC (Gotherstrom et al., 2003; Le Blanc, 2003) , alluding to their utility for allogeneic transplantation. In fact, hfMSC have been exploited for intrauterine cell therapy (Chan et al., 2007; Guillot et al., 2008; Kennea et al., 2009) , with the first successful clinical applications of hfMSC has been reported through allogeneic hfMSC transplantation in a fetus with osteogenesis imperfecta (Le Blanc et al., 2005).

\begin{tabular}{c|c|c}
\hline Immunologic properties & Fetal MSC & Adult MSC \\
\hline HLA Class I expression & $0-(++)^{*}$ & +++ \\
\hline $\begin{array}{c}\text { Intracellular deposits of } \\
\text { HLA Class II }\end{array}$ & 0 & +++ \\
\hline $\begin{array}{c}\text { Induction time to epxress } \\
\text { HLA Class II }\end{array}$ & $++(7$ days $)$ & $++(2$ days $)$ \\
\hline
\end{tabular}

“+" means positive, and " 0 " means no expression. *: no expression or lower

Table 3. Immunologic properties of fetal and adult MSC

Aside from their lower immunogenicity, faster proliferation rate and more robust osteogenic potential, hfMSC possess other favorable advantages over other cellular source, making them become an ideal off-the-shelf cellular candidate for BTE application (Table 4). Firstly, fetal tissues have a lower risk of viral and bacterial contamination compared to adult tissues as the fetus resides in an immunoprivileged environment within the uterus. Secondly, hfMSC have a higher proliferative capacity, and can undergo over 70 population doublings without senescence, compared to haMSC which typically senesces after 38 population doublings (Bruder et al., 1997; Campagnoli et al., 2001; Chan et al., 2005) . Theoretically, an unlimited number of cells can be derived from one hfMSC donor. With a proliferation capacity of more than 70 population doublings, theoretically one single cell isolated at Passage 0 can be proliferated to $1.2 \times 10^{21}\left(2^{70}\right)$ cells at Passage 70 and can be utilised more than $10^{12}$ patients (utilizing a dose of $1 \times 10^{9}$ cells). "Single-cell banks" can be established using cells derived from a single cell colony with well-investigated biological properties and 
greatly minimized variation; moreover, all the cells can be frozen down and made available off-the-shelf, eliminating the precious waiting time for patients. Lastly, the ethical conundrum faced with cells derived from embryonic stem cells are less of a problem with the use of fetal stem cells, considering that various human fetal cell types have been explored for therapeutic applications in the clinic already, such as the use of fetal neural progenitors for the treatment of Huntington's (Rosser and Dunnett, 2003) or Parkinson's disease (Clarkson, 2001), and the use of human fetal liver cells to treat severe immunodeficiencies, haematological disorders and inborn errors of metabolism (Touraine et al., 1993) . More recently human fetal skin cells have been utilized for constructing a tissue engineered skin graft (Hohlfeld et al., 2005; Pioletti et al., 2006).

\begin{tabular}{c|c|c|c|c|c}
\hline & Collection & Expansion & Storage & $\begin{array}{c}\text { Allogenic } \\
\text { applications }\end{array}$ & $\begin{array}{c}\text { Osteogenic } \\
\text { potential }\end{array}$ \\
\hline $\begin{array}{c}\text { Fresh bone } \\
\text { marrow }\end{array}$ & ++ & N.A. & N.A. & N.A.* & + \\
\hline $\begin{array}{c}\text { Differentiated } \\
\text { osteoblast }\end{array}$ & + & + & + & N.A.* & +++ \\
\hline $\begin{array}{c}\text { MSC from } \\
\text { adult BM }\end{array}$ & ++ & ++ & +++ & ++ & ++ \\
\hline $\begin{array}{c}\text { MSC from } \\
\text { fetal BM }\end{array}$ & ++ & +++ & +++ & +++ & +++ \\
\hline
\end{tabular}

N.A.*: allogenic applications can be achieved by proper HLA matching

Table 4. Comparison of hfMSC with other cellular source for BTE.

\section{Biaxial rotating bioreactors for BTE application}

Bioreactors are the biomechanical devices with closely monitored and tightly controlled environmental and operating conditions. Bioreactors have been widely used in industries for fermentation processing, wastewater treatment, food processing and production of pharmaceuticals. Recently bioreactors have been introduced to tissue engineering field in order to mimic the native in vivo environment and provide cellular tissue engineered constructs with physiologically relevant stimuli that facilitate and orchestrate the conversion of a "collection of cells" into a specific tissue phenotype (Lanza et al., 2007). Specifically, they can increase the mass transport to mitigate the diffusion limitation of 3D scaffolds, providing adequate nutrient, oxygen and regulatory molecules to the cells while removing metabolites and $\mathrm{CO}_{2}$ away. Bioreactors can provide proper physiological stimuli, especially the mechanical cues to trigger the mechanotransduction signaling pathway for the differentiation of cellular constructs, and can be used to enable efficient and homogenous cellular seeding in the complex 3D scaffolds. (Martin et al., 2004; Bilodeau and Mantovani, 2006; Chen and $\mathrm{Hu}, 2006$ )

Currently, several types of bioreactors such as spinner flasks, perfusion bioreactors and rotating wall vessel (RWV) bioreactors have been investigated for BTE applications. However, various limitations have been reported with the use of these bioreactors. Spinner flasks can improve fluid flow, which can lead to the enhanced cell proliferation, distribution and osteogenic differentiation (Mygind et al., 2007; Song et al., 2008; Stiehler et al., 2008), but the turbulence generated by stirring can be detrimental for seeded cells and newly laid 
down ECM (Sikavitsas et al., 2002; Chen and Hu, 2006). Perfusion bioreactors have been shown to enhance MSC proliferation and osteogenic differentiation in scaffold constructs (Sikavitsas et al., 2003; van et al., 2003; Gomes et al., 2006), however, they have been beset by non-homogenous cellular distributions, with cells at the frontal zones being washed away by the oncoming perfusion flow (Singh et al., 2007). Rotating wall vessel (RWV) bioreactors (Molnar et al., 1997; Granet et al., 1998; Yu et al., 2004), which generates low shear forces and three dimensional high mass transfer capacity, are prone to problems of non-homogenous cellular growth and ECM deposition (Goldstein et al., 2001; Sikavitsas et al., 2002; Chen and $\mathrm{Hu}$, 2006). Moreover, the free floating culture of RWV bioreactors usually lead to the collision between the scaffolds and the bioreactor walls, which can induce cellular damage and disrupt cellular attachment and matrix deposition on the scaffolds (Goldstein et al., 2001; Sikavitsas et al., 2002; Chen and $\mathrm{Hu}, 2006)$.

Consequently, we designed and developed an biaxial rotating bioreactor (Figure 7) to address the deficiencies found in current bioreactor designs. Firstly, a perfusion system was included to allow the media circulation between the vessel and reservoir, allowing maximal mass transfer with consequential low shear stress, and minimizing the washout problem associated with RWV bioreactors. Secondly, the improvement of biaxial rotation movement upon uni-axial rotating, leads to more homogenous cellular and ECM distribution of the scaffold, as previously predicted from in-silico simulation (Singh et al., 2005). Lastly, cellular scaffolds were secured by pins and were not kept in free suspension, avoiding the risk of scaffold collisions with the vessel walls.

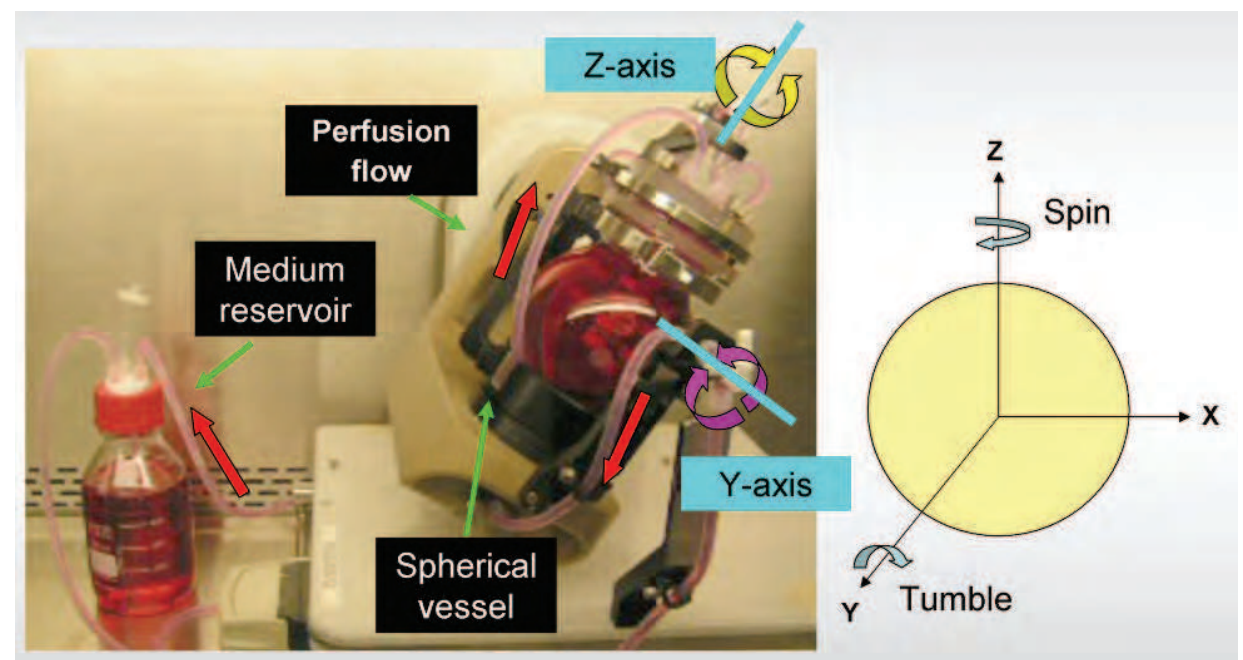

Fig. 7. The working mechanism of biaxial rotating bioreactor. This biaxial bioreactor can rotate in two perpendicular axes simultaneously with an inbuilt perfusion system.

In a recent study, we investigated the performance of this biaxial rotating bioreactor for generation of highly osteogenic bone graft using hfMSC mediated polycaprolactonetricalcium phosphate (PCL-TCP) scaffolds. hfMSC-scaffolds were cultured and matured in either bioreactor or static cultures, and evaluated for their cellular viability, proliferation 
and osteogenic differentiation in vitro, and after transplantation into immunodeficient mice. Compared with traditional static culture, biaxial bioreactor culture enhanced cellular proliferation, with hfMSC-scaffolds reached cellular confluence earlier (Day 7 vs Day 28) with greater cellularity $(2 \mathrm{x}, \mathrm{p}<0.01)$ (Figure 8$)$. Over 28 days of in vitro culture, the biaxial bioreactor enabled the maintenance of high cellular viability throughout the scaffolds, including the core, $2 \mathrm{~mm}$ from the surface of the scaffold. Thus the use of this bioreactor enabled a ten-fold improvement of mass transfer of nutrients, generally taken to be around 150-200 nm. In contrast, the static culture only allowed the cellular survival at a surface region of the thick scaffolds, with massive cell necrosis within the core of the scaffolds.

Biaxial bioreactor cultured-cellular scaffolds were associated with greater osteogenic induction as indicated by in vitro assays such as higher ALP expression $(1.5 \mathrm{x} p<0.01)$, more calcium deposition $(5.5 \mathrm{x}, \mathrm{p}<0.001)$ and bony nodule formation observed under scanning electron microscopy (SEM) (Figure 8A), and the in vivo ectopic bone formation in immunodeficient mice $(3.2 \mathrm{x}, \mathrm{p}<0.001)$ compared with static-cultured scaffolds. 


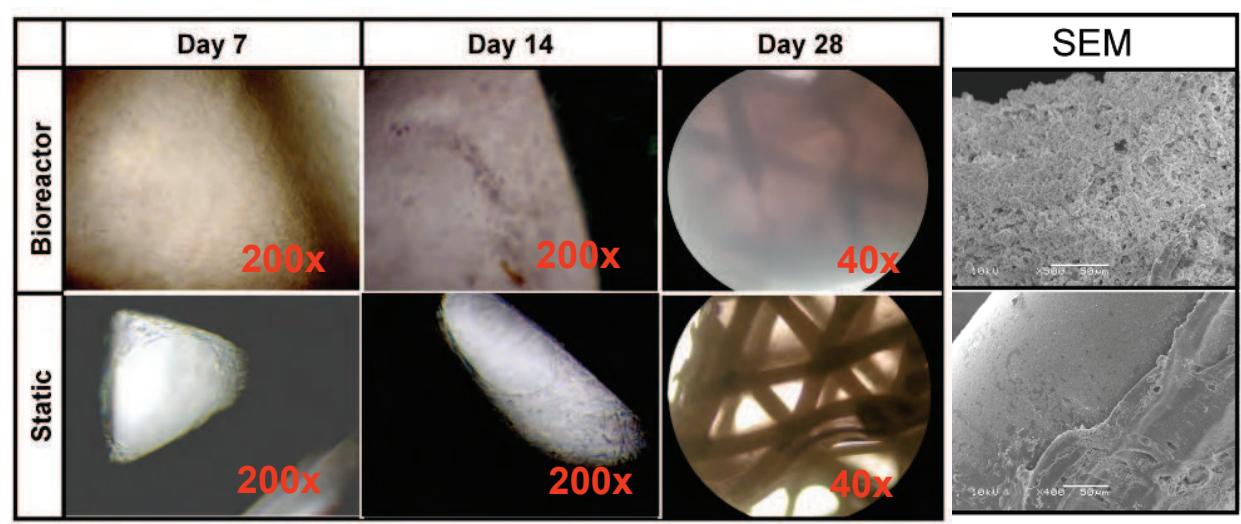

A. Prolfieration and differentiaiton of hfMSC scaffolds under bioreactor culture or static culture

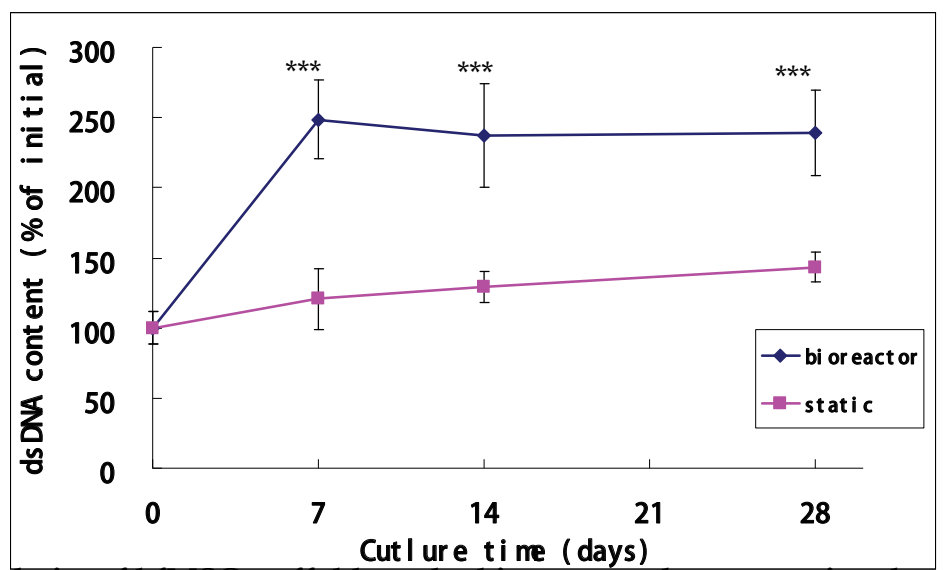

B. Cellularity of hfMSC scaffolds under bioreactor culture or static culture

Fig. 8. Comparison of the biaxial bioreactor culture and static culture. (A) Biaxial bioreactor cultured hfMSC scaffolds proliferated faster and underwent more robust osteogenic differentiation compared to static cultured ones, and (B) resulted in significantly higher cellularity in the cellular scaffolds $\left({ }^{* * *} \mathrm{p}<0.001\right)$.

\section{Conclusion -Generating effective TE bone grafts}

By combining an inter-disciplinary approach in scaffold technology, bioreactor development and stem cell biology, we have generated an effective bone graft through the seeding of highly proliferative and osteogenic hfMSC onto the osteoconductive PCL-TCP scaffold matrix, and maturing the hfMSC mediated PCL-TCP scaffold under biaxial rotating bioreactor (Figure 9). Our ongoing animal experiment showed that this hfMSC mediated TE bone graft can be used to heal critical sized femoral defect in a rat model (unpublished observations), paving the way for clinical trials to be initiated. This strategy presents a 
promising solution to fulfill the increasing need for bone grafts and provides effective TE bone grafts, which are available off-the-shelf like allografts and synthetic grafts and can stimulate rapid healing like autografts.

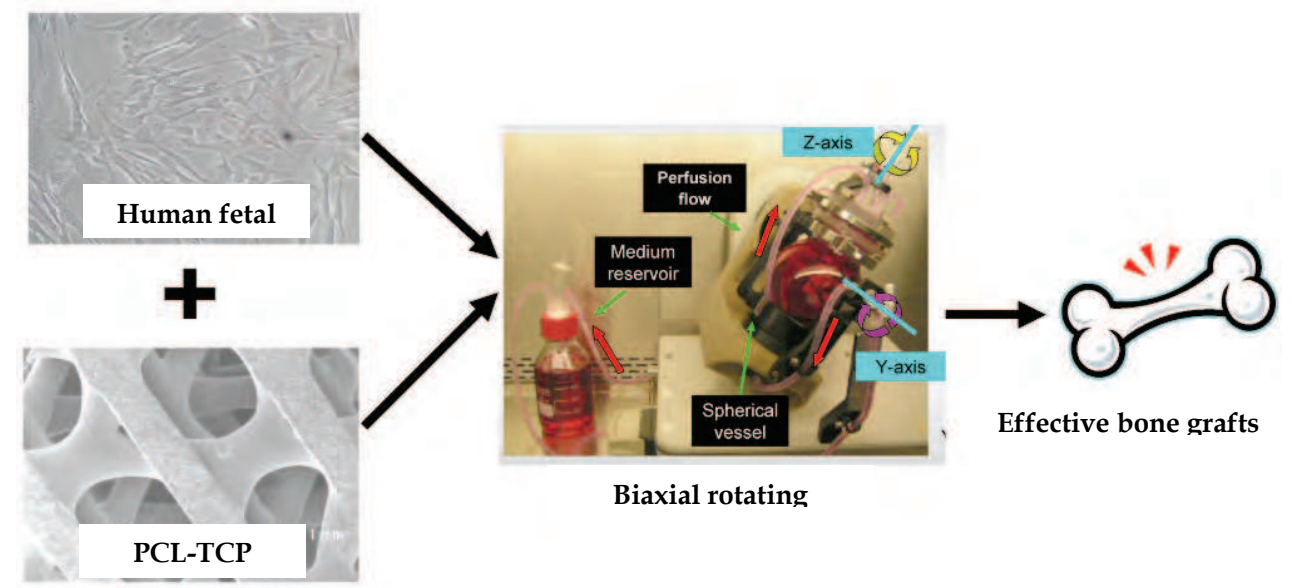

Fig. 9. Generation effective bone grafts with the combinational use of hfMSC, PCL-TCP scaffold and biaxial rotating bioreactor.

\section{References}

Aggarwal, S. and Pittenger, M. F. (2005). "Human mesenchymal stem cells modulate allogeneic immune cell responses." Blood 105 (4): 1815-22.

Agrawal, C. M. and Ray, R. B. (2001). "Biodegradable polymeric scaffolds for musculoskeletal tissue engineering." J Biomed Mater Res 55 (2): 141-50.

Almeida-Porada, G., El, S. D., Porada, C. and Zanjani, E. D. (2002). "Differentiative potential of human metanephric mesenchymal cells." Exp Hematol 30 (12): 1454-62.

Arrington, E. D., Smith, W. J., Chambers, H. G., Bucknell, A. L. and Davino, N. A. (1996). "Complications of iliac crest bone graft harvesting." Clin Orthop Relat Res(329): 300-9.

Aubin, J. E. (1998). "Bone stem cells." J Cell Biochem Suppl 30-31 : 73-82.

Aubin, J. E. (2001). "Regulation of osteoblast formation and function." Rev Endocr Metab Disord 2 (1): 81-94.

Baddoo, M., Hill, K., Wilkinson, R., Gaupp, D., Hughes, C., Kopen, G. C. and Phinney, D. G. (2003). "Characterization of mesenchymal stem cells isolated from murine bone marrow by negative selection." J Cell Biochem 89 (6): 1235-49.

Banas, A., Teratani, T., Yamamoto, Y., Tokuhara, M., Takeshita, F., Quinn, G., Okochi, H. and Ochiya, T. (2007). "Adipose tissue-derived mesenchymal stem cells as a source of human hepatocytes." Hepatology 46 (1): 219-28.

Banfi, A., Muraglia, A., Dozin, B., Mastrogiacomo, M., Cancedda, R. and Quarto, R. (2000). "Proliferation kinetics and differentiation potential of ex vivo expanded human 
bone marrow stromal cells: Implications for their use in cell therapy." Exp Hematol 28 (6): 707-15.

Banwart, J. C., Asher, M. A. and Hassanein, R. S. (1995). "Iliac crest bone graft harvest donor site morbidity. A statistical evaluation." Spine 20 (9): 1055-60.

Bartholomew, A., Sturgeon, C., Siatskas, M., Ferrer, K., McIntosh, K., Patil, S., Hardy, W., Devine, S., Ucker, D., Deans, R., Moseley, A. and Hoffman, R. (2002). "Mesenchymal stem cells suppress lymphocyte proliferation in vitro and prolong skin graft survival in vivo." Exp Hematol 30 (1): 42-8.

Beyth, S., Borovsky, Z., Mevorach, D., Liebergall, M., Gazit, Z., Aslan, H., Galun, E. and Rachmilewitz, J. (2005). "Human mesenchymal stem cells alter antigen-presenting cell maturation and induce T-cell unresponsiveness." Blood 105 (5): 2214-9.

Bieback, K., Kern, S., Kluter, H. and Eichler, H. (2004). "Critical parameters for the isolation of mesenchymal stem cells from umbilical cord blood." Stem Cells 22 (4): 625-34.

Bilodeau, K. and Mantovani, D. (2006). "Bioreactors for tissue engineering: focus on mechanical constraints. A comparative review." Tissue Eng 12 (8): 2367-83.

Blaker, J. J., Gough, J. E., Maquet, V., Notingher, I. and Boccaccini, A. R. (2003). "In vitro evaluation of novel bioactive composites based on Bioglass-filled polylactide foams for bone tissue engineering scaffolds." J Biomed Mater Res A 67 (4): 1401-11.

Bongso, A. (2005). Stem cells : from bench to bedside, New Jersey : World Scientific.

Bruder, S. P. and Fox, B. S. (1999). "Tissue engineering of bone. Cell based strategies." Clin Orthop Relat Res(367 Suppl): S68-83.

Bruder, S. P., Jaiswal, N. and Haynesworth, S. E. (1997). "Growth kinetics, self-renewal, and the osteogenic potential of purified human mesenchymal stem cells during extensive subcultivation and following cryopreservation." J Cell Biochem 64 (2): 278-94.

Bruder, S. P., Jaiswal, N. and Haynesworth, S. E. (1997). "Growth kinetics, self-renewal, and the osteogenic potential of purified human mesenchymal stem cells during extensive subcultivation and following cryopreservation." J Cell Biochem 64 (2): 278-94.

Campagnoli, C., Roberts, I. A., Kumar, S., Bennett, P. R., Bellantuono, I. and Fisk, N. M. (2001). "Identification of mesenchymal stem/progenitor cells in human firsttrimester fetal blood, liver, and bone marrow." Blood 98 (8): 2396-402.

Caplan, A. I. (1991). "Mesenchymal stem cells." J Orthop Res 9 (5): 641-50.

Caplan, A. I. (2005). "Review: mesenchymal stem cells: cell-based reconstructive therapy in orthopedics." Tissue Eng 11 (7-8): 1198-211.

Caplan, A. I. (2007). "Adult mesenchymal stem cells for tissue engineering versus regenerative medicine." J Cell Physiol 213 (2): 341-7.

Chan, J.; O' Donoghue, K; de, Fuente J; Roberts, I A; Kumar, S; Morgan, J E; Fisk, N. M. (2005). "Human fetal mesenchymal stem cells as vehicles for gene delivery." Stem Cells 23 (1): 93-102.

Chan, J., Waddington, S. N., O, D. K., Kurata, H., Guillot, P. V., Gotherstrom, C., Themis, M., Morgan, J. E. and Fisk, N. M. (2007). "Widespread distribution and muscle differentiation of human fetal mesenchymal stem cells after intrauterine transplantation in dystrophic mdx mouse." Stem Cells 25 (4): 875-84.

Chen, H. C. and Hu, Y. C. (2006). "Bioreactors for tissue engineering." Biotechnol Lett 28 (18): 1415-23. 
Ciapetti, G., Ambrosio, L., Savarino, L., Granchi, D., Cenni, E., Baldini, N., Pagani, S., Guizzardi, S., Causa, F. and Giunti, A. (2003). "Osteoblast growth and function in porous poly epsilon -caprolactone matrices for bone repair: a preliminary study." Biomaterials 24 (21): 3815-24.

Clarkson, E. D. (2001). "Fetal tissue transplantation for patients with Parkinson's disease: a database of published clinical results." Drugs Aging 18 (10): 773-85.

Colter, D. C., Class, R., DiGirolamo, C. M. and Prockop, D. J. (2000). "Rapid expansion of recycling stem cells in cultures of plastic-adherent cells from human bone marrow." Proc Natl Acad Sci U S A 97 (7): 3213-8.

Colter, D. C., Sekiya, I. and Prockop, D. J. (2001). "Identification of a subpopulation of rapidly self-renewing and multipotential adult stem cells in colonies of human marrow stromal cells." Proc Natl Acad Sci U S A 98 (14): 7841-5.

Connolly, J. F., Guse, R., Tiedeman, J. and Dehne, R. (1989). "Autologous marrow injection for delayed unions of the tibia: a preliminary report." J Orthop Trauma 3 (4): 276-82.

Connolly, J. F., Guse, R., Tiedeman, J. and Dehne, R. (1991). "Autologous marrow injection as a substitute for operative grafting of tibial nonunions." Clin Orthop Relat $\operatorname{Res}(266):$ 259-70.

Coombes, A. G., Rizzi, S. C., Williamson, M., Barralet, J. E., Downes, S. and Wallace, W. A. (2004). "Precipitation casting of polycaprolactone for applications in tissue engineering and drug delivery." Biomaterials 25 (2): 315-25.

Damien, C. J. and Parsons, J. R. (1991). "Bone graft and bone graft substitutes: a review of current technology and applications." J Appl Biomater 2 (3): 187-208.

De, B. C., Dell, A. F., Tylzanowski, P. and Luyten, F. P. (2001). "Multipotent mesenchymal stem cells from adult human synovial membrane." Arthritis Rheum 44 (8): 1928-42.

De, C. P., Bartsch, G. J., Siddiqui, M. M., Xu, T., Santos, C. C., Perin, L., Mostoslavsky, G., Serre, A. C., Snyder, E. Y., Yoo, J. J., Furth, M. E., Soker, S. and Atala, A. (2007). "Isolation of amniotic stem cell lines with potential for therapy." Nat Biotechnol 25 (1): 100-6.

De, K. I., Hicok, K. C., Padilla, R. J., Young, R. G. and Cooper, L. F. (2006). "Effect of vitamin D pretreatment of human mesenchymal stem cells on ectopic bone formation." J Oral Implantol 32 (3): 103-9.

Digirolamo, C. M., Stokes, D., Colter, D., Phinney, D. G., Class, R. and Prockop, D. J. (1999). "Propagation and senescence of human marrow stromal cells in culture: a simple colony-forming assay identifies samples with the greatest potential to propagate and differentiate." Br J Haematol 107 (2): 275-81.

Digirolamo, C. M., Stokes, D., Colter, D., Phinney, D. G., Class, R. and Prockop, D. J. (1999). "Propagation and senescence of human marrow stromal cells in culture: a simple colony-forming assay identifies samples with the greatest potential to propagate and differentiate." Br J Haematol 107 (2): 275-81.

Djouad, F., Plence, P., Bony, C., Tropel, P., Apparailly, F., Sany, J., Noel, D. and Jorgensen, C. (2003). "Immunosuppressive effect of mesenchymal stem cells favors tumor growth in allogeneic animals." Blood 102 (10): 3837-44.

Dominici, M., Le, B. K., Mueller, I., Slaper-Cortenbach, I., Marini, F., Krause, D., Deans, R., Keating, A., Prockop, D. and Horwitz, E. (2006). "Minimal criteria for defining multipotent mesenchymal stromal cells. The International Society for Cellular Therapy position statement." Cytotherapy 8 (4): 315-7. 
Dudas, J. R., Marra, K. G., Cooper, G. M., Penascino, V. M., Mooney, M. P., Jiang, S., Rubin, J. P. and Losee, J. E. (2006). "The osteogenic potential of adipose-derived stem cells for the repair of rabbit calvarial defects." Ann Plast Surg 56 (5): 543-8.

Eghbali-Fatourechi, G. Z., Lamsam, J., Fraser, D., Nagel, D., Riggs, B. L. and Khosla, S. (2005). "Circulating osteoblast-lineage cells in humans." N Engl J Med 352 (19): 1959-66.

Einhorn, T. A. (1995). "Enhancement of fracture-healing." J Bone Joint Surg Am 77 (6): 94056.

Britannica, E. (2007). The New Encyclopaedia Britannica, 2007 Edition, Encyclopedia Britannica, Incorporated.

Endres, M., Hutmacher, D. W., Salgado, A. J., Kaps, C., Ringe, J., Reis, R. L., Sittinger, M., Brandwood, A. and Schantz, J. T. (2003). "Osteogenic induction of human bone marrow-derived mesenchymal progenitor cells in novel synthetic polymerhydrogel matrices." Tissue Eng 9 (4): 689-702.

Fowler, B. L., Dall, B. E. and Rowe, D. E. (1995). "Complications associated with harvesting autogenous iliac bone graft." Am J Orthop 24 (12): 895-903.

Friedenstein, A. J., Petrakova, K. V., Kurolesova, A. I. and Frolova, G. P. (1968). "Heterotopic of bone marrow.Analysis of precursor cells for osteogenic and hematopoietic tissues." Transplantation 6 (2): 230-47.

Friedenstein, A. J., Piatetzky, S. I. and Petrakova, K. V. (1966). "Osteogenesis in transplants of bone marrow cells." J Embryol Exp Morphol 16 (3): 381-90.

Gang, E. J., Jeong, J. A., Han, S., Yan, Q., Jeon, C. J. and Kim, H. (2006). "In vitro endothelial potential of human UC blood-derived mesenchymal stem cells." Cytotherapy 8 (3): 215-27.

Giannoudis, P. V., Einhorn, T. A. and Marsh, D. (2007). "Fracture healing: a harmony of optimal biology and optimal fixation?" Injury 38 Suppl 4 : S1-2.

Goldstein, A. S., Juarez, T. M., Helmke, C. D., Gustin, M. C. and Mikos, A. G. (2001). "Effect of convection on osteoblastic cell growth and function in biodegradable polymer foam scaffolds." Biomaterials 22 (11): 1279-88.

Gomes, M. E., Bossano, C. M., Johnston, C. M., Reis, R. L. and Mikos, A. G. (2006). "In vitro localization of bone growth factors in constructs of biodegradable scaffolds seeded with marrow stromal cells and cultured in a flow perfusion bioreactor." Tissue Eng 12 (1): $177-88$.

Gotherstrom, C. (2007). "Immunomodulation by multipotent mesenchymal stromal cells." Transplantation 84 (1 Suppl): S35-7.

Gotherstrom, C., Ringden, O., Westgren, M., Tammik, C. and Le, B. K. (2003). "Immunomodulatory effects of human foetal liver-derived mesenchymal stem cells." Bone Marrow Transplant 32 (3): 265-72.

Goulet, J. A., Senunas, L. E., DeSilva, G. L. and Greenfield, M. L. (1997). "Autogenous iliac crest bone graft. Complications and functional assessment." Clin Orthop Relat $\operatorname{Res}(339):$ 76-81.

Granet, C., Laroche, N., Vico, L., Alexandre, C. and Lafage-Proust, M. H. (1998). "Rotatingwall vessels, promising bioreactors for osteoblastic cell culture: comparison with other 3D conditions." Med Biol Eng Comput 36 (4): 513-9.

Guillot, P. V., Abass, O., Bassett, J. H., Shefelbine, S. J., Bou-Gharios, G., Chan, J., Kurata, H., Williams, G. R., Polak, J. and Fisk, N. M. (2008). "Intrauterine transplantation of 
human fetal mesenchymal stem cells from first-trimester blood repairs bone and reduces fractures in osteogenesis imperfecta mice." Blood 111 (3): 1717-25.

Hayda, R. A., Brighton, C. T. and Esterhai, J. L. (1998). "Pathophysiology of delayed healing." Clin Orthop Relat Res(355 Suppl): S31-40.

Hohlfeld, J., de, B. R., Hirt-Burri, N., Chaubert, P., Gerber, S., Scaletta, C., Hohlfeld, P. and Applegate, L. A. (2005). "Tissue engineered fetal skin constructs for paediatric burns." Lancet 366 (9488): 840-2.

Hollinger, J. O., Brekke, J., Gruskin, E. and Lee, D. (1996). "Role of bone substitutes." Clin Orthop Relat Res(324): 55-65.

Hollinger, J. O., Einhorn, T. A., Doll, B. A. and Sfeir, C. (2005). Bone Tissue Engineering, Boca Raton : CRC Press.

Hu, Y., Liao, L., Wang, Q., Ma, L., Ma, G., Jiang, X. and Zhao, R. C. (2003). "Isolation and identification of mesenchymal stem cells from human fetal pancreas." J Lab Clin Med 141 (5): 342-9.

Hutmacher, D. W. (2000). "Scaffolds in tissue engineering bone and cartilage." Biomaterials 21 (24): 2529-43.

Hutmacher, D. W., Schantz, T., Zein, I., Ng, K. W., Teoh, S. H. and Tan, K. C. (2001). "Mechanical properties and cell cultural response of polycaprolactone scaffolds designed and fabricated via fused deposition modeling." J Biomed Mater Res 55 (2): 203-16.

Hutmacher, D. W., Schantz, T., Zein, I., Ng, K. W., Teoh, S. H. and Tan, K. C. (2001). "Mechanical properties and cell cultural response of polycaprolactone scaffolds designed and fabricated via fused deposition modeling." J Biomed Mater Res 55 (2): 203-16.

Inoue, K., Ohgushi, H., Yoshikawa, T., Okumura, M., Sempuku, T., Tamai, S. and Dohi, Y. (1997). "The effect of aging on bone formation in porous hydroxyapatite: biochemical and histological analysis." J Bone Miner Res 12 (6): 989-94.

in't Anker P ; Noort, W A; Scherjon, S A; Kleijburg-van, Keur C; Kruisselbrink, A B; van, Bezooijen R; Beekhuizen, W; Willemze, R; Kanhai, H H; Fibbe, W. E. (2003). "Mesenchymal stem cells in human second-trimester bone marrow, liver, lung, and spleen exhibit a similar immunophenotype but a heterogeneous multilineage differentiation potential." Haematologica 88 (8): 845-52.

in't Anker, P; Scherjon, S A; Kleijburg-van, Keur C; Noort, W A; Claas, F H; Willemze, R; Fibbe, W E; Kanhai, H. H. (2003). "Amniotic fluid as a novel source of mesenchymal stem cells for therapeutic transplantation." Blood 102 (4): 1548-9.

Javazon, E. H., Colter, D. C., Schwarz, E. J. and Prockop, D. J. (2001). "Rat marrow stromal cells are more sensitive to plating density and expand more rapidly from singlecell-derived colonies than human marrow stromal cells." Stem Cells 19 (3): 219-25.

Lieberman, J. R. and Friedlaender, G. E. (2005). Bone Regeneration and Repair: Biology and Clinical Applications, Humana Press.

Jiang, Y., Jahagirdar, B. N., Reinhardt, R. L., Schwartz, R. E., Keene, C. D., Ortiz-Gonzalez, X. R., Reyes, M., Lenvik, T., Lund, T., Blackstad, M., Du, J., Aldrich, S., Lisberg, A., Low, W. C., Largaespada, D. A. and Verfaillie, C. M. (2002). "Pluripotency of mesenchymal stem cells derived from adult marrow." Nature 418 (6893): 41-9.

Bilezikian, J. P. (2002). Principles of Bone Biology, Academic Press. 
Jones, E. and McGonagle, D. (2008). "Human bone marrow mesenchymal stem cells in vivo." Rheumatology (Oxford) 47 (2): 126-31.

Kahn, A., Gibbons, R., Perkins, S. and Gazit, D. (1995). "Age-related bone loss. A hypothesis and initial assessment in mice." Clin Orthop Relat Res(313): 69-75.

Kennea, N. L., Waddington, S. N., Chan, J., O, D. K., Yeung, D., Taylor, D. L., Al-Allaf, F. A., Pirianov, G., Themis, M., Edwards, A. D., Fisk, N. M. and Mehmet, H. (2009). "Differentiation of human fetal mesenchymal stem cells into cells with an oligodendrocyte phenotype." Cell Cycle 8 (7): 1069-79.

Kimelman, N., Pelled, G., Helm, G. A., Huard, J., Schwarz, E. M. and Gazit, D. (2007). "Review: gene- and stem cell-based therapeutics for bone regeneration and repair." Tissue Eng 13 (6): 1135-50.

Klyushnenkova, E., Mosca, J. D., Zernetkina, V., Majumdar, M. K., Beggs, K. J., Simonetti, D. W., Deans, R. J. and McIntosh, K. R. (2005). "T cell responses to allogeneic human mesenchymal stem cells: immunogenicity, tolerance, and suppression." J Biomed Sci 12 (1): 47-57.

Kokubo, T., Kim, H. M. and Kawashita, M. (2003). "Novel bioactive materials with different mechanical properties." Biomaterials 24 (13): 2161-75.

Kokubu, T., Hak, D. J., Hazelwood, S. J. and Reddi, A. H. (2003). "Development of an atrophic nonunion model and comparison to a closed healing fracture in rat femur." J Orthop Res 21 (3): 503-10.

Krampera, M., Glennie, S., Dyson, J., Scott, D., Laylor, R., Simpson, E. and Dazzi, F. (2003). "Bone marrow mesenchymal stem cells inhibit the response of naive and memory antigen-specific T cells to their cognate peptide." Blood 101 (9): 3722-9.

Lam, C. X., Hutmacher, D. W., Schantz, J. T., Woodruff, M. A. and Teoh, S. H. (2008). "Evaluation of polycaprolactone scaffold degradation for 6 months in vitro and in vivo." J Biomed Mater Res A.

Lane, J. M., Tomin, E. and Bostrom, M. P. (1999). "Biosynthetic bone grafting." Clin Orthop Relat Res(367 Suppl): S107-17.

Langer, R. and Vacanti, J. P. (1993). "Tissue engineering." Science 260 (5110): 920-6.

Laurencin, C. T., Ambrosio, A. M., Borden, M. D. and Cooper, J. A. (1999). "Tissue engineering: orthopedic applications." Annu Rev Biomed Eng 1 : 19-46.

Le Blanc, K. (2003). "Immunomodulatory effects of fetal and adult mesenchymal stem cells." Cytotherapy 5 (6): 485-9.

Le Blanc, K., Frassoni, F., Ball, L., Locatelli, F., Roelofs, H., Lewis, I., Lanino, E., Sundberg, B., Bernardo, M. E., Remberger, M., Dini, G., Egeler, R. M., Bacigalupo, A., Fibbe, W. and Ringden, O. (2008). "Mesenchymal stem cells for treatment of steroid-resistant, severe, acute graft-versus-host disease: a phase II study." Lancet 371 (9624): 1579-86.

Le Blanc, K., Gotherstrom, C., Ringden, O., Hassan, M., McMahon, R., Horwitz, E., Anneren, G., Axelsson, O., Nunn, J., Ewald, U., Norden-Lindeberg, S., Jansson, M., Dalton, A., Astrom, E. and Westgren, M. (2005). "Fetal mesenchymal stem-cell engraftment in bone after in utero transplantation in a patient with severe osteogenesis imperfecta." Transplantation 79 (11): 1607-14.

Le Blanc, K., Tammik, C., Rosendahl, K., Zetterberg, E. and Ringden, O. (2003). "HLA expression and immunologic properties of differentiated and undifferentiated mesenchymal stem cells." Exp Hematol 31 (10): 890-6. 
Le Blanc, K., Tammik, L., Sundberg, B., Haynesworth, S. E. and Ringden, O. (2003). "Mesenchymal stem cells inhibit and stimulate mixed lymphocyte cultures and mitogenic responses independently of the major histocompatibility complex." Scand J Immunol 57 (1): 11-20.

Lee, O. K., Kuo, T. K., Chen, W. M., Lee, K. D., Hsieh, S. L. and Chen, T. H. (2004). "Isolation of multipotent mesenchymal stem cells from umbilical cord blood." Blood 103 (5): 1669-75.

LeGeros, R. Z. (2002). "Properties of osteoconductive biomaterials: calcium phosphates." Clin Orthop Relat Res(395): 81-98.

Logeart-Avramoglou, D., Anagnostou, F., Bizios, R. and Petite, H. (2005). "Engineering bone: challenges and obstacles." J Cell Mol Med 9 (1): 72-84.

Maitra, B., Szekely, E., Gjini, K., Laughlin, M. J., Dennis, J., Haynesworth, S. E. and Koc, O. N. (2004). "Human mesenchymal stem cells support unrelated donor hematopoietic stem cells and suppress T-cell activation." Bone Marrow Transplant 33 (6): 597-604.

Maquet, V., Boccaccini, A. R., Pravata, L., Notingher, I. and Jerome, R. (2004). "Porous poly(alpha-hydroxyacid)/Bioglass composite scaffolds for bone tissue engineering. I: Preparation and in vitro characterisation." Biomaterials 25 (18): 4185-94.

Marsh, D. (1998). "Concepts of fracture union, delayed union, and nonunion." Clin Orthop Relat Res(355 Suppl): S22-30.

Marsh, D. R. and Li, G. (1999). "The biology of fracture healing: optimising outcome." $\mathrm{Br}$ Med Bull 55 (4): 856-69.

Martin, I., Wendt, D. and Heberer, M. (2004). "The role of bioreactors in tissue engineering." Trends Biotechnol 22 (2): 80-6.

Mauney, J. R., Jaquiery, C., Volloch, V., Heberer, M., Martin, I. and Kaplan, D. L. (2005). "In vitro and in vivo evaluation of differentially demineralized cancellous bone scaffolds combined with human bone marrow stromal cells for tissue engineering." Biomaterials 26 (16): 3173-85.

Mendes, S. C., Sleijster, M., den Van, M., De, B. J. and Van, B. C. (2002). "A cultured living bone equivalent enhances bone formation when compared to a cell seeding approach." J Mater Sci Mater Med 13 (6): 575-81.

Molnar, G., Schroedl, N. A., Gonda, S. R. and Hartzell, C. R. (1997). "Skeletal muscle satellite cells cultured in simulated microgravity." In Vitro Cell Dev Biol Anim 33 (5): 38691.

Montjovent, M. O., Burri, N., Mark, S., Federici, E., Scaletta, C., Zambelli, P. Y., Hohlfeld, P., Leyvraz, P. F., Applegate, L. L. and Pioletti, D. P. (2004). "Fetal bone cells for tissue engineering." Bone 35 (6): 1323-33.

Mueller, S. M. and Glowacki, J. (2001). "Age-related decline in the osteogenic potential of human bone marrow cells cultured in three-dimensional collagen sponges." J Cell Biochem 82 (4): 583-90.

Muraglia, A., Cancedda, R. and Quarto, R. (2000). "Clonal mesenchymal progenitors from human bone marrow differentiate in vitro according to a hierarchical model." J Cell Sci 113 ( Pt 7) : 1161-6.

Muraglia, A., Cancedda, R. and Quarto, R. (2000). "Clonal mesenchymal progenitors from human bone marrow differentiate in vitro according to a hierarchical model." J Cell Sci 113 ( Pt 7) : 1161-6. 
Mygind, T., Stiehler, M., Baatrup, A., Li, H., Zou, X., Flyvbjerg, A., Kassem, M. and Bunger, C. (2007). "Mesenchymal stem cell ingrowth and differentiation on coralline hydroxyapatite scaffolds." Biomaterials 28 (6): 1036-47.

Nakahara, H., Dennis, J. E., Bruder, S. P., Haynesworth, S. E., Lennon, D. P. and Caplan, A. I. (1991). "In vitro differentiation of bone and hypertrophic cartilage from periostealderived cells." Exp Cell Res 195 (2): 492-503.

Okumura, M., Ohgushi, H., Dohi, Y., Katuda, T., Tamai, S., Koerten, H. K. and Tabata, S. (1997). "Osteoblastic phenotype expression on the surface of hydroxyapatite ceramics." J Biomed Mater Res 37 (1): 122-9.

Ong, S. Y., Dai, H. and Leong, K. W. (2006). "Hepatic differentiation potential of commercially available human mesenchymal stem cells." Tissue Eng 12 (12): 347785.

Oswald, J., Boxberger, S., Jorgensen, B., Feldmann, S., Ehninger, G., Bornhauser, M. and Werner, C. (2004). "Mesenchymal stem cells can be differentiated into endothelial cells in vitro." Stem Cells 22 (3): 377-84.

Parikh, S. N. (2002). "Bone graft substitutes: past, present, future." J Postgrad Med 48 (2): 142-8.

Phinney, D. G., Kopen, G., Righter, W., Webster, S., Tremain, N. and Prockop, D. J. (1999). "Donor variation in the growth properties and osteogenic potential of human marrow stromal cells." J Cell Biochem 75 (3): 424-36.

Pioletti, D. P., Montjovent, M. O., Zambelli, P. Y. and Applegate, L. (2006). "Bone tissue engineering using foetal cell therapy." Swiss Med Wkly 136 (35-36): 557-60.

Pittenger, M. F., Mackay, A. M., Beck, S. C., Jaiswal, R. K., Douglas, R., Mosca, J. D., Moorman, M. A., Simonetti, D. W., Craig, S. and Marshak, D. R. (1999). "Multilineage potential of adult human mesenchymal stem cells." Science 284 (5411): 143-7.

Prolo, D. J. and Rodrigo, J. J. (1985). "Contemporary bone graft physiology and surgery." Clin Orthop Relat Res(200): 322-42.

Quarto, R., Mastrogiacomo, M., Cancedda, R., Kutepov, S. M., Mukhachev, V., Lavroukov, A., Kon, E. and Marcacci, M. (2001). "Repair of large bone defects with the use of autologous bone marrow stromal cells." N Engl J Med 344 (5): 385-6.

Rai, B., Ho, K. H., Lei, Y., Si-Hoe, K. M., Jeremy, T. C., Yacob, K. B., Chen, F., Ng, F. C. and Teoh, S. H. (2007). "Polycaprolactone-20\% tricalcium phosphate scaffolds in combination with platelet-rich plasma for the treatment of critical-sized defects of the mandible: a pilot study." J Oral Maxillofac Surg 65 (11): 2195-205.

Rai, B., Oest, M. E., Dupont, K. M., Ho, K. H., Teoh, S. H. and Guldberg, R. E. (2007). "Combination of platelet-rich plasma with polycaprolactone-tricalcium phosphate scaffolds for segmental bone defect repair." J Biomed Mater Res A 81 (4): 888-99.

Rai, B., Teoh, S. H., Ho, K. H., Hutmacher, D. W., Cao, T., Chen, F. and Yacob, K. (2004). "The effect of rhBMP-2 on canine osteoblasts seeded onto 3D bioactive polycaprolactone scaffolds." Biomaterials 25 (24): 5499-506.

Rasmusson, I., Ringden, O., Sundberg, B. and Le, B. K. (2003). "Mesenchymal stem cells inhibit the formation of cytotoxic $\mathrm{T}$ lymphocytes, but not activated cytotoxic $\mathrm{T}$ lymphocytes or natural killer cells." Transplantation 76 (8): 1208-13. 
Reyes, M., Lund, T., Lenvik, T., Aguiar, D., Koodie, L. and Verfaillie, C. M. (2001). "Purification and ex vivo expansion of postnatal human marrow mesodermal progenitor cells." Blood 98 (9): 2615-25.

Lanza, R., Langer, R. and Vacanti, J. (2007). Principles of Tissue Engineering, Third Edition, Academic Press.

Rodriguez, J. P., Montecinos, L., Rios, S., Reyes, P. and Martinez, J. (2000). "Mesenchymal stem cells from osteoporotic patients produce a type I collagen-deficient extracellular matrix favoring adipogenic differentiation." J Cell Biochem 79 (4): 557 65.

Rosser, A. E. and Dunnett, S. B. (2003). "Neural transplantation in patients with Huntington's disease." CNS Drugs 17 (12): 853-67.

Rouwkema, J., Rivron, N. C. and van, B. C. (2008). "Vascularization in tissue engineering." Trends Biotechnol.

Rzhaninova, A. A., Gornostaeva, S. N. and Goldshtein, D. V. (2005). "Isolation and phenotypical characterization of mesenchymal stem cells from human fetal thymus." Bull Exp Biol Med 139 (1): 134-40.

Sakaguchi, Y., Sekiya, I., Yagishita, K., Ichinose, S., Shinomiya, K. and Muneta, T. (2004). "Suspended cells from trabecular bone by collagenase digestion become virtually identical to mesenchymal stem cells obtained from marrow aspirates." Blood 104 (9): 2728-35.

Salgado, A. J., Coutinho, O. P. and Reis, R. L. (2004). "Bone tissue engineering: state of the art and future trends." Macromol Biosci 4 (8): 743-65.

Salgado, A. J., Coutinho, O. P. and Reis, R. L. (2004). "Bone tissue engineering: state of the art and future trends." Macromol Biosci 4 (8): 743-65.

Sarugaser, R., Lickorish, D., Baksh, D., Hosseini, M. M. and Davies, J. E. (2005). "Human umbilical cord perivascular (HUCPV) cells: a source of mesenchymal progenitors." Stem Cells 23 (2): 220-9.

Schantz, J. T., Hutmacher, D. W., Chim, H., Ng, K. W., Lim, T. C. and Teoh, S. H. (2002). "Induction of ectopic bone formation by using human periosteal cells in combination with a novel scaffold technology." Cell Transplant 11 (2): 125-38.

Schimming, R. and Schmelzeisen, R. (2004). "Tissue-engineered bone for maxillary sinus augmentation." J Oral Maxillofac Surg 62 (6): 724-9.

Service, R. F. (2000). "Tissue engineers build new bone." Science 289 (5484): 1498-500.

Sgodda, M., Aurich, H., Kleist, S., Aurich, I., Konig, S., Dollinger, M. M., Fleig, W. E. and Christ, B. (2007). "Hepatocyte differentiation of mesenchymal stem cells from rat peritoneal adipose tissue in vitro and in vivo." Exp Cell Res 313 (13): 2875-86.

Sikavitsas, V. I., Bancroft, G. N., Holtorf, H. L., Jansen, J. A. and Mikos, A. G. (2003). "Mineralized matrix deposition by marrow stromal osteoblasts in 3D perfusion culture increases with increasing fluid shear forces." Proc Natl Acad Sci U S A 100 (25): 14683-8.

Sikavitsas, V. I., Bancroft, G. N. and Mikos, A. G. (2002). "Formation of three-dimensional cell/polymer constructs for bone tissue engineering in a spinner flask and a rotating wall vessel bioreactor." J Biomed Mater Res 62 (1): 136-48.

Sikavitsas, V. I., Bancroft, G. N. and Mikos, A. G. (2002). "Formation of three-dimensional cell/polymer constructs for bone tissue engineering in a spinner flask and a rotating wall vessel bioreactor." J Biomed Mater Res 62 (1): 136-48. 
Sikavitsas, V. I., van, D. J., Bancroft, G. N., Jansen, J. A. and Mikos, A. G. (2003). "Influence of the in vitro culture period on the in vivo performance of cell/titanium bone tissueengineered constructs using a rat cranial critical size defect model." J Biomed Mater Res A 67 (3): 944-51.

Simmons, P. J. and Torok-Storb, B. (1991). "Identification of stromal cell precursors in human bone marrow by a novel monoclonal antibody, STRO-1." Blood 78 (1): 55-62.

Singh, H., Ang, E. S., Lim, T. T. and Hutmacher, D. W. (2007). "Flow modeling in a novel non-perfusion conical bioreactor." Biotechnol Bioeng 97 (5): 1291-9.

Singh, H., Teoh, S. H., Low, H. T. and Hutmacher, D. W. (2005). "Flow modelling within a scaffold under the influence of uni-axial and bi-axial bioreactor rotation." J Biotechnol 119 (2): 181-96.

Song, K., Liu, T., Cui, Z., Li, X. and Ma, X. (2008). "Three-dimensional fabrication of engineered bone with human bio-derived bone scaffolds in a rotating wall vessel bioreactor." J Biomed Mater Res A 86 (2): 323-32.

Stiehler, M., Bunger, C., Baatrup, A., Lind, M., Kassem, M. and Mygind, T. (2008). "Effect of dynamic 3-D culture on proliferation, distribution, and osteogenic differentiation of human mesenchymal stem cells." J Biomed Mater Res A.

Suzuki, Y., Kim, K. J., Kotake, S. and Itoh, T. (2001). "Stromal cell activity in bone marrow from the tibia and iliac crest of patients with rheumatoid arthritis." J Bone Miner Metab 19 (1): 56-60.

Touraine, J. L., Roncarolo, M. G., Bacchetta, R., Raudrant, D., Rebaud, A., Laplace, S., Cesbron, P., Gebuhrer, L., Zabot, M. T., Touraine, F. and et (1993). "Fetal liver transplantation: biology and clinical results." Bone Marrow Transplant 11 Suppl 1 : 119-22.

Ueda, M., Yamada, Y., Kagami, H. and Hibi, H. (2008). "Injectable bone applied for ridge augmentation and dental implant placement: human progress study." Implant Dent 17 (1): 82-90.

van, D. J., Bancroft, G. N., Sikavitsas, V. I., Spauwen, P. H., Jansen, J. A. and Mikos, A. G. (2003). "Flow perfusion culture of marrow stromal osteoblasts in titanium fiber mesh." J Biomed Mater Res A 64 (2): 235-41.

Weissman, I. L. (2000). "Translating stem and progenitor cell biology to the clinic: barriers and opportunities." Science 287 (5457): 1442-6.

Woodbury, D., Schwarz, E. J., Prockop, D. J. and Black, I. B. (2000). "Adult rat and human bone marrow stromal cells differentiate into neurons." J Neurosci Res 61 (4): 364-70.

Yamada, Y., Nakamura, S., Ito, K., Kohgo, T., Hibi, H., Nagasaka, T. and Ueda, M. (2008). "Injectable tissue-engineered bone using autogenous bone marrow-derived stromal cells for maxillary sinus augmentation: clinical application report from a 2-6-year follow-up." Tissue Eng Part A 14 (10): 1699-707.

Yu, X., Botchwey, E. A., Levine, E. M., Pollack, S. R. and Laurencin, C. T. (2004). "Bioreactorbased bone tissue engineering: the influence of dynamic flow on osteoblast phenotypic expression and matrix mineralization." Proc Natl Acad Sci U S A 101 (31): 11203-8.

Zein, I., Hutmacher, D. W., Tan, K. C. and Teoh, S. H. (2002). "Fused deposition modeling of novel scaffold architectures for tissue engineering applications." Biomaterials 23 (4): 1169-85. 
Zhang, Z. Y., Teoh, S. H., Chong, M. S., Schantz, J. T., Fisk, N. M., Choolani, M. A. and Chan, J. (2009). "Superior Osteogenic Capacity for Bone Tissue Engineering of Fetal Compared To Perinatal and Adult Mesenchymal Stem Cells." Stem Cells 27 (1): 12637.

Zhang, Z. Y., Teoh, S. H., Chong, W. S., Foo, T. T., Chng, Y. C., Choolani, M. and Chan, J. (2009). "A biaxial rotating bioreactor for the culture of fetal mesenchymal stem cells for bone tissue engineering." Biomaterials 30 (14): 2694-704.

Zhao, L. R., Duan, W. M., Reyes, M., Keene, C. D., Verfaillie, C. M. and Low, W. C. (2002). "Human bone marrow stem cells exhibit neural phenotypes and ameliorate neurological deficits after grafting into the ischemic brain of rats." Exp Neurol 174 (1): 11-20.

Zhao, Z., Liao, L., Cao, Y., Jiang, X. and Zhao, R. C. (2005). "Establishment and properties of fetal dermis-derived mesenchymal stem cell lines: plasticity in vitro and hematopoietic protection in vivo." Bone Marrow Transplant 36 (4): 355-65.

Zuk, P. A., Zhu, M., Mizuno, H., Huang, J., Futrell, J. W., Katz, A. J., Benhaim, P., Lorenz, H. P. and Hedrick, M. H. (2001). "Multilineage cells from human adipose tissue: implications for cell-based therapies." Tissue Eng 7 (2): 211-28. 


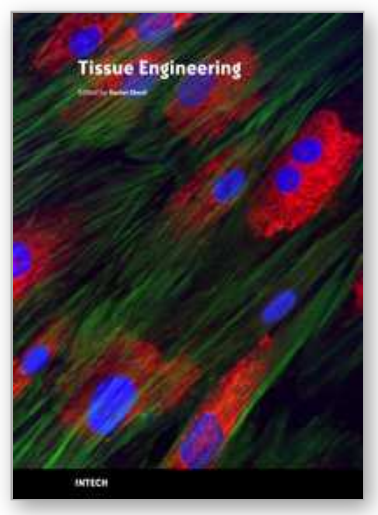

\author{
Tissue Engineering \\ Edited by Daniel Eberli
}

ISBN 978-953-307-079-7

Hard cover, 524 pages

Publisher InTech

Published online 01, March, 2010

Published in print edition March, 2010

The Tissue Engineering approach has major advantages over traditional organ transplantation and circumvents the problem of organ shortage. Tissues that closely match the patient's needs can be reconstructed from readily available biopsies and subsequently be implanted with minimal or no immunogenicity. This eventually conquers several limitations encountered in tissue transplantation approaches. This book serves as a good starting point for anyone interested in the application of Tissue Engineering. It offers a colorful mix of topics, which explain the obstacles and possible solutions for TE applications.

\title{
How to reference
}

In order to correctly reference this scholarly work, feel free to copy and paste the following:

Zhiyong Zhang, Swee-Hin Teoh, Mahesh Choolani and Jerry Chan (2010). Development of Human Fetal Mesenchymal Stem Cell Mediated Tissue Engineering Bone Grafts, Tissue Engineering, Daniel Eberli (Ed.), ISBN: 978-953-307-079-7, InTech, Available from: http://www.intechopen.com/books/tissue-

engineering/development-of-human-fetal-mesenchymal-stem-cell-mediated-tissue-engineering-bone-grafts

\section{INTECH}

open science | open minds

\section{InTech Europe}

University Campus STeP Ri

Slavka Krautzeka 83/A

51000 Rijeka, Croatia

Phone: +385 (51) 770447

Fax: +385 (51) 686166

www.intechopen.com

\section{InTech China}

Unit 405, Office Block, Hotel Equatorial Shanghai

No.65, Yan An Road (West), Shanghai, 200040, China

中国上海市延安西路65号上海国际贵都大饭店办公楼405单元

Phone: +86-21-62489820

Fax: +86-21-62489821 
(C) 2010 The Author(s). Licensee IntechOpen. This chapter is distributed under the terms of the Creative Commons Attribution-NonCommercialShareAlike-3.0 License, which permits use, distribution and reproduction for non-commercial purposes, provided the original is properly cited and derivative works building on this content are distributed under the same license. 